\title{
Mitochondrial proteomics of nasopharyngeal carcinoma metastasis
}

Jianping Liu' ${ }^{1,2,3,4}$, Xianquan Zhan ${ }^{1,2^{*}}$, Maoyu Li ${ }^{1,2}$, Guoqing Li ${ }^{1,2,5}$, Pengfei Zhang ${ }^{1}$, Zhefeng Xiao ${ }^{1,2}$, Meiying Shao ${ }^{1,2}$, Fang Peng ${ }^{1,2}$, Rong $\mathrm{Hu}^{1,2}$ and Zhuchu Chen ${ }^{1,2^{*}}$

\begin{abstract}
Background: Mitochondrial proteomic alterations of nasopharyngeal carcinoma metastasis remain unknown. Our purpose is to screen mitochondrial proteins for the elucidation of the molecular mechanisms of nasopharyngeal carcinoma metastasis and the discovery of metastasis-related biomarkers.
\end{abstract}

Methods: Mitochondria were isolated from nasopharyngeal carcinoma metastatic (5-8F) and nonmetastatic (6-10B) cell lines, respectively. After characterization of isolated mitochondria, mitochondrial differentially expressed proteins (DEPs) were quantified by two-dimensional difference in-gel electrophoresis (2D-DIGE), and identified by peptide mass fingerprint (PMF) and tandem mass spectrometry (MS/MS). A functional enrichment analysis and a protein-protein interaction sub-network analysis for DEPs were carried out with bioinformatics. Furthermore, siRNAs transient transfections were used to suppress expressions of some up-regulated DEPs in metastatic cells (5-8F), followed by Transwell Migration assay.

Results: Sixteen mitochondrial DEPs including PRDX3 and SOD2 were identified. Those 5-8F cells with suppression of PRDX3 showed an increased mobility potential. The functional enrichment analyses of DEPs discovered five significant biological processes including cellular response to reactive oxygen species, hydrogen peroxide metabolic process, regulation of mitochondrial membrane potential, cell redox homeostasis and oxidation reduction, and five significant molecular functions including oxidoreductase activity, caspase inhibitor activity, peroxiredoxin activity, porin activity and antioxidant activity. A protein-protein interaction sub-network of DEPs was generated with literature data. Ten mitochondrial DEPs including PRDX3, PRDX6, SOD2, ECH1, SERPINB5, COX5A, PDIA5, EIF5A, $\mathrm{IDH} 3 \mathrm{~B}$, and PSMC4 were rationalized in the tumor-stroma co-evolution model that mitochondrial oxidative stress directly contributes to tumor metastasis.

Conclusions: Sixteen mitochondrial DEPs were identified with mass spectrometry and ten of them were rationalized in the tumor-stroma co-evolution model. Those 5-8F cells with suppression of PRDX3 showed an increased mobility potential. These data suggest that those mitochondrial DEPs are potential biomarkers for NPC metastasis, and their dysregulation would play important roles in mitochondria oxidative stress-mediated NPC metastatic process.

Keywords: Nasopharyngeal carcinoma, Tumor metastasis, Mitochondria, Proteome, Differentially expressed proteins, Functional enrichment analysis, Literature data mining, PRDX3

\footnotetext{
* Correspondence: yjzhan2011@gmail.com; tcbl@xysm.net

${ }^{1}$ Key Laboratory of Cancer Proteomics of Chinese Ministry of Health, Xiangya

Hospital, Central South University, 87 Xiangya Road, Changsha, Hunan

410008, P.R. China

${ }^{2}$ Hunan Engineering Laboratory for Structural Biology and Drug Design,

Xiangya Hospital, Central South University, 87 Xiangya Road, Changsha,

Hunan 410008, P.R. China

Full list of author information is available at the end of the article
}

\section{Biomed Central}

(C) 2012 Liu et al.; licensee BioMed Central Ltd. This is an Open Access article distributed under the terms of the Creative Commons Attribution License (http://creativecommons.org/licenses/by/2.0), which permits unrestricted use, distribution, and reproduction in any medium, provided the original work is properly cited. 


\section{Background}

Nasopharyngeal carcinoma (NPC) cell lines 5-8F and 610B are derived from the same human cell line SUNE1 that is derived from a female poorly differentiated nasopharyngeal squamous epithelial cell carcinoma. Those two cell sublines $5-8 \mathrm{~F}$ and $6-10 \mathrm{~B}$ with the same genetic background have tumorigenic ability that was confirmed by the colony formation in soft agar and in vivo mouse model, but are quite different in metastatic potential [1$3]$. 5-8F cells are metastatic and 6-10B cells are nonmetastatic, which was confirmed by in vivo mouse model [2]. This different biological character shows that these two cell sublines are the useful experiment materials to study the molecular events of NPC metastasis. Based on those two subcelines, some research groups analyzed the differentially expressed genes (DEGs) and differentially expressed proteins (DEPs) using the whole-cell samples of those two cell lines. A total of 78 DEGs were identified with subtractive suppression hybridization [4] and microarray [5]. Of them, 11 DEGs including PTHLH formed a metastasis-related gene network [5]. A total of 28 DEPs were identified with two-dimensional gel electrophoresis (2DGE) coupled with matrix-assisted laser desorption ionization time-of-flight mass spectrometry (MALDI-TOF MS) [6,7]. Those DEPs were related to apoptosis, cell cycle, cell signal transduction, cell survival, transcription regulation, cell mobility, protein synthesis, and DNA damage repair [6,7]. However, those DEGs and DEPs were not fully rationalized in the biological process of NPC metastasis, and there is no any overlap between those 78 DEGs and 28 DEPs [4-7]. It would be derived from the following limitation factors: (i) the range of the protein abundance of the whole-cell sample is too wide, not all proteins were extracted; (ii) 2DGE only can array very small partial components of a whole-cell proteome, and (iii) the process of translation of DEG to DEP is regulated by multiple factors, which results in the low consistence between the DEG and DEP profiles. The subcellular proteomics such as just focusing on one compartment of a cell would more effectively discover function-related proteins because the subcellular proteome is much simpler than the wholecell proteome, it can maximally identify the protein components in a subcellular proteome.

Many evidences have demonstrated that mitochondria is the central to oxidative stress, and tumor cell self has anti-oxidant ability for its survival and metastasis [8-15]. Mitochondria are not just innocent bystander in cancer, but are related to tumorigenesis, apoptosis, cancer therapy and metastasis. The contribution of mitochondria to cancer involves three critical processes including alterations in glucose metabolism, production of reactive oxygen species (ROS), and compromise of intrinsic apoptotic function $[8,9]$. According to the tumor-stroma co-evolution model opinion, cancer cells secrete hydrogen peroxide, induce oxidative stress in adjacent stromal cells, and result in an excess production of ROS in mitochondria. Excess stromal ROS induces cytoskeleton rearrangements, autophagy, and mitophagy in the tumor microenvironment to help cancer cells escape excess ROS in the primary tumor site, also induces the stromal over-production of recycled nutrients such as ketones and L-lactate that are fuel for tumor growth and metastasis [10-14]. This model provides fresh insight of how mitochondria involved in tumor metastasis. Therefore, a tight relationship exists between mitochondria and tumor metastasis. However, the causes, consequences, and other series of related questions regarding molecular mechanism of mictochondria in tumor metastasis still remain unclear. Thus, this current work focused on the mitochondrial proteome difference between metastatic 5$8 \mathrm{~F}$ and $6-10 \mathrm{~B}$ cells, and provided clues to clarification of the functional role of mitochondria in the process of NPC metastasis.

In order to screen mitochondrial proteins for the elucidation of the mechanism of NPC metastasis and the discovery of metastasis-related biomarkers, twodimensional difference in-gel electrophoresis (2D-DIGE) was used to determine mitochondrial DEPs between metastatic 5-8F and nonmetastastic 6-10B cells, followed by protein characterization with peptide mass fingerprint (PMF) and tandem mass spectrometry (MS/MS). siRNA transient transfection was used to suppress the expressions of up-regulated DEPs in metastatic 5-8F cells, followed by the observation of changes in cell mobility potential by Transwell Migration assay. Cytoscape BiNGO plugin was used for gene ontology (GO) analyses of DEPs to identify the enriched biological processes and molecular functions. A protein-protein interaction subnetwork of DEPs was generated with literature data mining from HPRD and NCBI databases. Ten DEPs were rationalized in a tumor-stroma co-evolution model, and associated with tumor metastasis.

\section{Results}

\section{Characterization of isolated mitochondria}

The purity of isolated mitochondria was assessed by Western blotting and electron microscopic observations. Figure 1A showed Western blotting images of extracted proteins from isolated mitochondrial samples against known marker proteins from cytoplasm (LDH), mitochondria (COX IV), nucleus (PCNA), endoplasmic reticulum (GRP 78), peroxisome (catalase), and lysosome (Cathepsin D). Mitochondrial protein COX IV was specifically detected in isolated mitochondrial sample and this sample lacked any detectable contamination of abundant cytosolic (LDH), nuclear (PCNA), and endoplasmic reticulum proteins (GRP78), except for detectable contamination of catalase from peroxisome and cathepsin $\mathrm{D}$ from lysosome. 


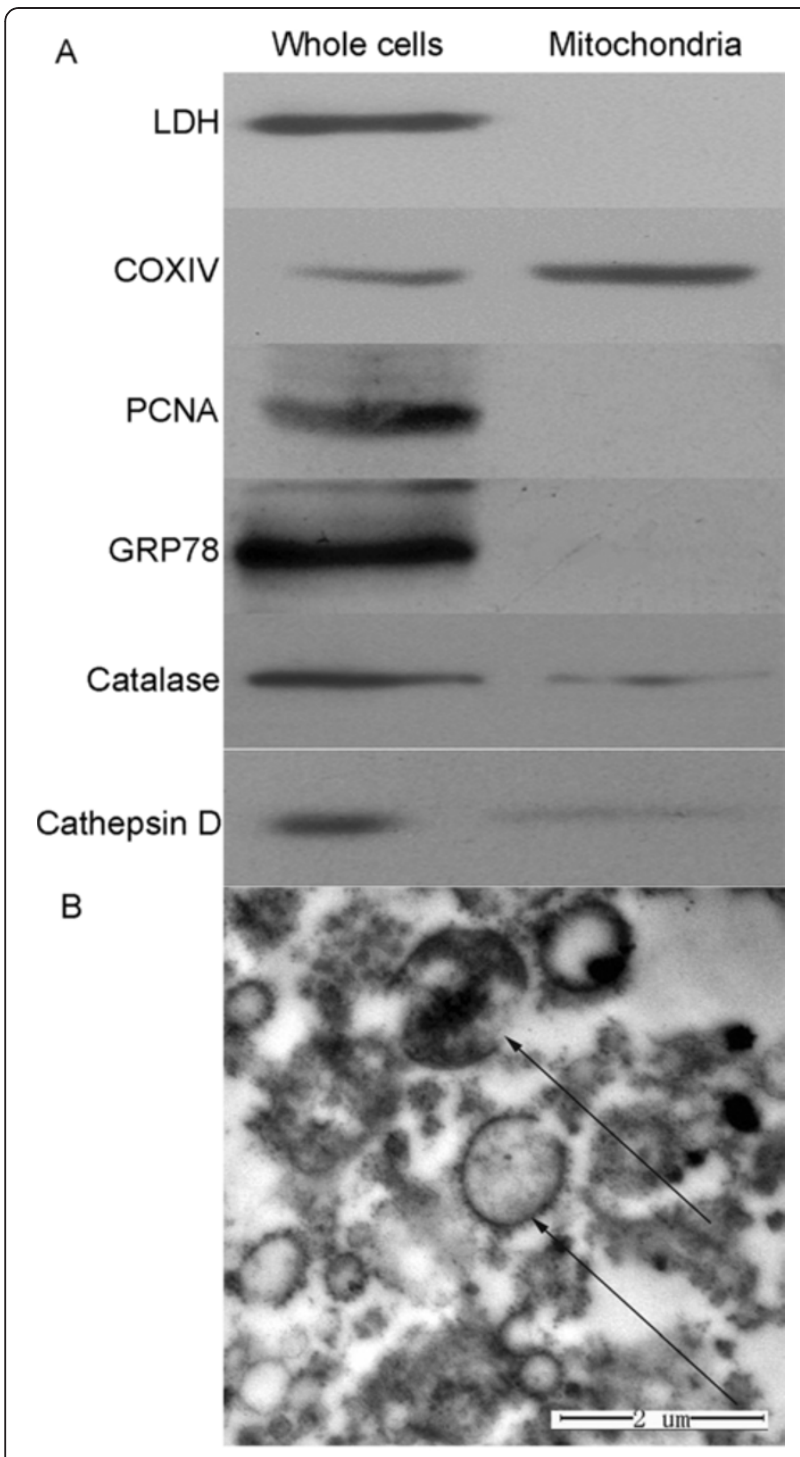

Figure 1 Characterization of isolated mitochondria from cells. A. Western blotting images of 6 marker proteins in the whole-cell protein samples (left column) and the isolated mitochondrial protein samples (right column). A total of $60 \mu \mathrm{g}$ proteins was loaded and isolated by $12 \%$ SDS-PAGE, and transferred to PVDF membrane and incubated with primary antibodies (dilution 1:500) of each marker protein and second antibodies (dilution 1:2,000). B. Electron micrograph of isolated mitochondrial samples from cells $(20,000 \times)$.

Figure 1B showed electron microscopic observation of isolated mitochondrial samples, where mitochondria had typical membrane architecture. All the results showed that isolated mitochondrial samples were full of intact mitochondria, though little contaminated by other sub-cellular compartments.

\section{Detection of mitochondrial DEPs between metastatic and nonmetastatic cells by 2D-DIGE}

Mitochondrial protein expressions were compared between metastatic 5-8F and nonmetastatic 6-10B cells using 2D-DIGE with a mixed-sample internal standard. After comparative analyses by DeCyder 5.0 software in all 9 protein-spot image maps, average of $1,047 \pm 78$ proteinspots were detected, in total 36 spots containing DEPs (Xfold $\left._{5-8 \mathrm{~F} / 6-10 \mathrm{~B}}>2, \quad \mathrm{P}<0.05\right)$ were detected. Figure $2 \mathrm{~A}$ showed a representative two-color merged gel image. Figure $2 \mathrm{~B}$ showed 36 spots containing DEPs. Figure $2 \mathrm{C}$ showed the three-dimensional simulation, a close-up of the region of 2D-DIGE gel image, and the associated graph view of an up-regulated protein (spot 2). Figure 2D showed the three-dimensional simulation, a close-up of the region of $2 \mathrm{D}$-DIGE gel image, and the associated graph view of a down-regulated protein (spot 15).

\section{Identification of mitochondrial DEPs between metastatic and nonmetastatic cells by PMF and MS/MS}

All of 36 gel-spots that contained DEPs were excised from the stained preparative gel. The proteins in each excised gel spot were subjected to in situ digestion with trypsin, and analyzed with MALDI-TOF PMF and ESI-Q-TOF MS/MS. All PMF-based identification data were collected in the supplementary mass spectral data (Additional file 1: Figures 1-13). All MS/MS-based identification data were collected in the supplementary mass spectral data (Additional file 1: Figures 14-19). A total of 16 DEPs were identified, including 4 down-regulated proteins (IDH3B, COX5A, SERPINB5, and MRPL12) and 12 up-regulated proteins (PRDX3, PRDX6, SOD2, PDIA5, ETFA, VDAC1, VDAC2, ECH1, PHB, EIF5A, PSMC4, and CALU) (Table 1). Those DEPs function in mitochondria ATP synthesis, ion transport, hydrogen peroxide metabolic process, DNA damage response, apoptosis, cell redox homeostasis, respiratory electron transport, fatty acid beta-oxidation, regulation of transcription, protein biosynthesis, and mitochondrial membrane potential.

\section{Functional enrichment analyses of mitochondrial DEPs and protein-protein interaction data}

Functional enrichment categories that characterized mitochondrial DEPs were identified. The functional enrichment maps of biological process (Figure 3) and molecular function (Figure 4) were shown. The statistical significantly enriched biological processes and molecular functions $(\mathrm{p}<0.05)$ were listed in Table 2 . Biological processes such as cellular response to reactive oxygen species, hydrogen peroxide metabolic process, regulation of mitochondrial membrane potential, cell redox homestasis, and oxidation reduction were enriched. Molecular functions such as oxidoreductase activity, caspase inhibitor activity, peroxiredoxin activity, porin activity, and antioxidant activity were enriched. These results obviously showed that chiefly enriched proteins for the identified mitochondrial DEPs were oxidoreducition-related 


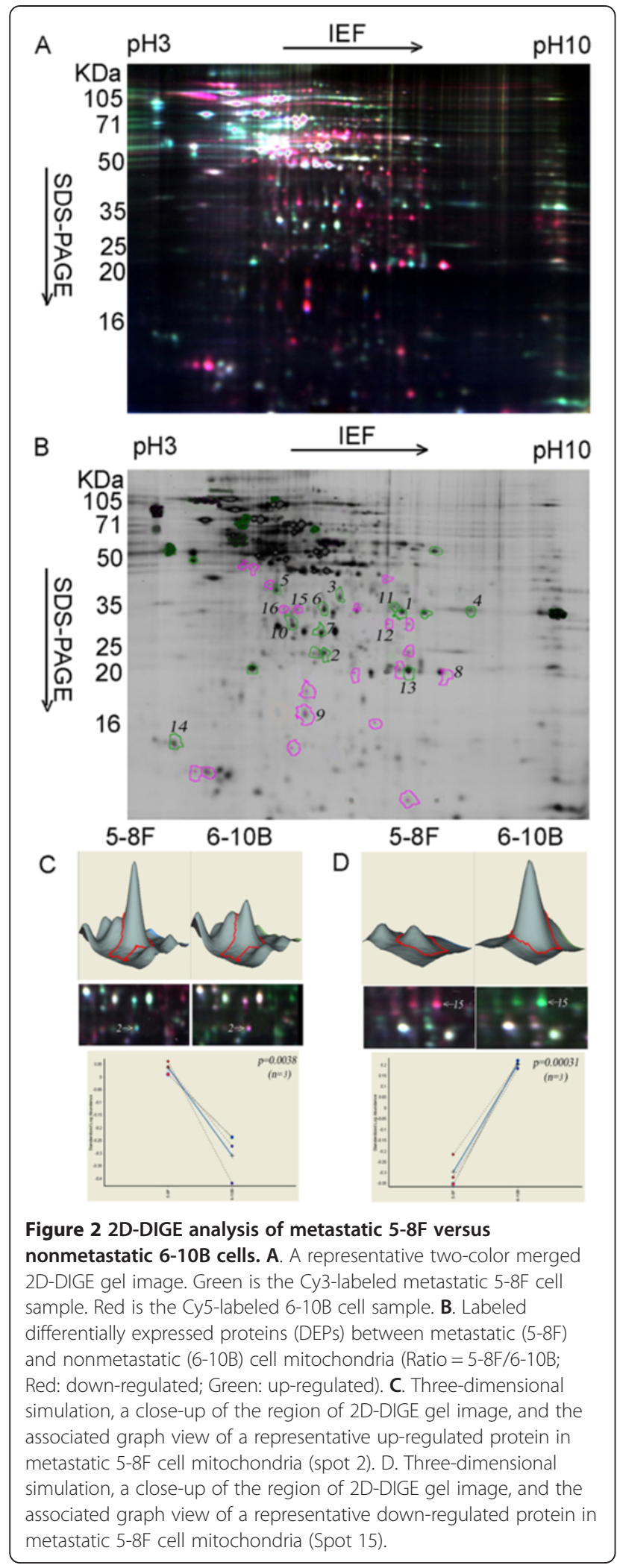

proteins and chiefly enriched biological processes were oxidoreducition-related processes.

After data extraction from HPRD and NCBI databases, a protein-protein interaction sub-network of mitochondrial DEPs was generated. These results only extended one layer connection, contained 193 nodes and 252 edges (Figure 5). In this complex sub-network, the colored circles (nodes) represented proteins and the blue full lines (edges) represented protein-protein interactions. The nodes representing 16 DEPs were labeled in yellow (up-regulated) or green (down-regulated). Seven DEPs that interacted more proteins were VDAC1, VDAC2, PRDX3, PRDX6, SOD2, PHB, and PSMC4. These interaction data provided important clues to insight into the molecular mechanisms of NPC metastasis.

\section{Validation of PRDX3 expression in mitochondria of} metastatic and nonmetastatic cells by Western blotting Western blotting was conducted to confirm differential expression of PRDX3 in mitochondria of metastatic 5-8F cells compared with nonmetastic 6-10B cells. Equal amount $(60 \mu \mathrm{g})$ of mitochondrial proteins of metastatic $5-8 \mathrm{~F}$ and nonmetastatic $6-10 \mathrm{~B}$ cells were applied to $12 \%$ SDS-PAGE and then transferred to PVDF membranes using COX IV as internal standard. The results showed that PRDX3 was significantly up-regulated (about 240\%) in mitochondria of metastatic 5-8F cells relative to nonmetastatic 6-10B cells (Figure 6). It was consistent with the 2D-DIGE result.

\section{Efficiency of PRDX3 siRNA transient transfection in mitochondria of metastatic $5-8 \mathrm{~F}$ cells}

Efficiency of the PRDX3 siRNA (sc-40833) transient transfection of metastatic 5-8F cells was tested with Western Blotting, using a scrambled sequence siRNA (sc-44230) as control. The result data showed PRDX3 expression in mitochondria of metastatic 5-8F cells with PRDX3 siRNA transient transfection was down-regulated (about 65\%) compared with metastatic 5-8F cells without PRDX3 siRNA transient transfection (Figure 7). It demonstrates that expression of PRDX3 was inhibited in the mitochondria of NPC metastatic 5-8F cells with PRDX3 siRNA treatment.

\section{Count of metastatic $5-8 \mathrm{~F}$ cells migrated in Transwell Migration assay}

In three independent experiments, the number of cells migrated through Transwell insert membrane was counted for four experimental groups: Group A (nonmetastatic $6-10 \mathrm{~B}$ cells; $0 \pm 0$ ), Group B (metastatic 5-8F cells; $647 \pm 35$ ), Group C (metastatic 5-8F cells with PRDX3 siRNA transient transfection; $838 \pm 31$ ), and Group D (metastatic 5-8F cells with a scramble sequence 
Table 1 Differentially expressed proteins in mitochondria of metastatic 5-8F compared to non-metastatic 6-10B cells, identified by 2D-DIGE and MS (Ratio = 5-8F/6-10B; +, up-regulated; -, down-regulated)

\begin{tabular}{|c|c|c|c|c|c|c|c|c|c|c|c|c|}
\hline Proteins names & $\begin{array}{l}\text { Spots } \\
\text { no. }\end{array}$ & $\begin{array}{l}\text { Accession } \\
\text { number }\end{array}$ & $\begin{array}{l}\text { Gene } \\
\text { names }\end{array}$ & $\begin{array}{l}\text { Subcellular } \\
\text { location }\end{array}$ & $\begin{array}{l}\text { Mass } \\
\text { (Da) }\end{array}$ & $\mathrm{pl}$ & $\begin{array}{l}\text { Mascot } \\
\text { score }\end{array}$ & NMP & NUP & MOI & $\begin{array}{l}\text { Sequence } \\
\text { coverage } \\
(\%)\end{array}$ & $\begin{array}{l}\text { Average } \\
\text { ratio }\end{array}$ \\
\hline \multicolumn{13}{|l|}{ 1. Oxidoreductase Proteins } \\
\hline Peroxiredoxin 3 & 2 & $\begin{array}{l}\text { gi| } \\
119569781\end{array}$ & PRDX3 & Mitochondria & 24,941 & 5.73 & 90 & 5 & 9 & PMF & 43 & +2.2 \\
\hline Peroxiredoxin 6 & 10 & gi|4758638 & PRDX6 & $\begin{array}{l}\text { Mitochondria, } \\
\text { lysosome }\end{array}$ & 25,133 & 8.36 & 71 & 5 & 8 & PMF & 21 & +2.5 \\
\hline Superoxide dismutase & 13 & $\begin{array}{l}\text { gil } \\
67782309\end{array}$ & SOD2 & Mitochondria & 20,882 & 8.36 & 71 & 4 & 4 & PMF & 52 & +3.3 \\
\hline $\begin{array}{l}\text { [Mn], mitochondrial isoform B } \\
\text { precursor }\end{array}$ & & & & & & & 62 & 2 & 1 & $\begin{array}{l}\text { MS/ } \\
\text { MS }\end{array}$ & 8 & \\
\hline Isocitrate dehydrogenase & 12 & gi|5031777 & $\mathrm{IDH} 3 \mathrm{~B}$ & Mitochondria & 40,022 & 6.47 & 75 & 6 & 10 & PMF & 15 & -3.3 \\
\hline $\begin{array}{l}\text { [NAD] subunit alpha, } \\
\text { mitochondrial precursor }\end{array}$ & & & & & & & 73 & 1 & $\backslash$ & $\begin{array}{l}\text { MS/ } \\
\text { MS }\end{array}$ & 3 & \\
\hline $\begin{array}{l}\text { Protein disulfide isomerase } \\
\text { related protein } 5\end{array}$ & 5 & gi|1710248 & PDIA5 & $\begin{array}{l}\text { Endoplasmic } \\
\text { reticulum }\end{array}$ & 46,512 & 4.95 & 166 & 9 & 4 & PMF & 37 & +2.4 \\
\hline $\begin{array}{l}\text { Cytochrome c oxidase subunit } \\
5 \mathrm{~A} \text {, mitochondrial precursor }\end{array}$ & 9 & $\begin{array}{l}\text { gi| } \\
190885499\end{array}$ & COX5A & Mitochondria & 16,923 & 6.30 & 72 & 4 & 3 & PMF & 38 & -4.4 \\
\hline Electron transfer & 6 & gi|2781202 & ETFA & Mitochondria & 33,418 & 6.95 & 73 & 4 & 2 & PMF & 27 & +2.6 \\
\hline flavoprotein & & & & & & & 95 & 3 & 1 & $\begin{array}{l}\text { MS/ } \\
\text { MS }\end{array}$ & 11 & \\
\hline \multicolumn{13}{|l|}{ 2. Porin Proteins } \\
\hline $\begin{array}{l}\text { Volatage-dependent anion } \\
\text { selective channel protein } 1\end{array}$ & 4 & gi|4507879 & VDAC1 & Mitochondria & 30,868 & 8.62 & 117 & 7 & 8 & PMF & 38 & +2.4 \\
\hline $\begin{array}{l}\text { Volatage-dependent anion } \\
\text { channel } 2\end{array}$ & 1 & $\begin{array}{l}\text { gi| } \\
55664661\end{array}$ & VDAC2 & Mitochondria & 30,842 & 8.00 & 101 & 6 & 5 & PMF & 34 & +2.2 \\
\hline \multicolumn{13}{|l|}{$\begin{array}{l}\text { 3. Metabolism and regulation } \\
\text { Proteins }\end{array}$} \\
\hline $\begin{array}{l}\text { Delta(3.5)-Delta(2.4)-dienovl- } \\
\text { CoA isomerase, mitochondrial } \\
\text { precursor }\end{array}$ & 11 & $\begin{array}{l}\text { gil } \\
70995211\end{array}$ & $\mathrm{ECH} 1$ & Mitochondria & 36,136 & 8.16 & 105 & 7 & 10 & PMF & 44 & +4.1 \\
\hline Prohibitin & 7 & gi|4505773 & PHB & Mitochondria & 29.843 & 5.57 & 158 & 8 & 1 & PMF & 44 & +2.0 \\
\hline Maspin & 15 & $\begin{array}{l}\text { gil } \\
56554671\end{array}$ & SERPINB5 & $\begin{array}{l}\text { Extracellular } \\
\text { region }\end{array}$ & 43,690 & 5.99 & 225 & 5 & 1 & $\begin{array}{l}\text { MS/ } \\
\text { MS }\end{array}$ & 15 & -3.2 \\
\hline Eukaryotic initiation factor $5 \mathrm{~A}$ & 14 & gi|4261795 & EIF5A & $\begin{array}{l}\text { Endoplasmic } \\
\text { reticulum }\end{array}$ & 17,018 & 4.85 & 68 & 3 & 1 & $\begin{array}{l}\text { MS/ } \\
\text { MS }\end{array}$ & 15 & +3.2 \\
\hline $\begin{array}{l}265 \text { protease regulatory } \\
\text { subunit } 7 \text { isoform } 1\end{array}$ & 3 & gi|4506209 & PSMC4 & $\begin{array}{l}\text { Mitochondria, } \\
\text { proteasome }\end{array}$ & 49,002 & 5.71 & 92 & 6 & 2 & PMF & 19 & +2.0 \\
\hline $\begin{array}{l}\text { Ribosomal protein L7/L12, } \\
\text { mitochondria }\end{array}$ & 8 & gi|1313962 & MRPL12 & Mitochindria & 21,593 & 9.04 & 86 & 4 & 1 & $\begin{array}{l}\text { MS/ } \\
\text { MS }\end{array}$ & 19 & -3.9 \\
\hline Calumenin isoform c precursor & 16 & $\begin{array}{l}\text { gil } \\
314122177\end{array}$ & CALU & $\begin{array}{l}\text { Endoplasmic } \\
\text { reticulum }\end{array}$ & 38,141 & 4.47 & 124 & 8 & 9 & PMF & 31 & +2.9 \\
\hline
\end{tabular}

NMP, the number of matched peptides. NUP, the number of unmatched peptides. MOI, methods of identification.

siRNA transient transfection; $593 \pm 27$ ). The number of Group $\mathrm{C}$ was about $40 \%$ more than the number of Group B and Group D ( $<<0.05)$. The effect of PRDX3 siRNA transient transfection on migration capability of metastatic 5-8F cells was showed (Figure 8). It demonstrates that suppression of PRDX3 in metastatic 5-8F cells increased its mobility potential.

\section{Discussion}

Nasopharyngeal carcinoma (NPC) is a malignant tumor with a high incidence of metastasis, has a great tendency to invade adjacent regions and metastasize to regional lymph node and distant organs. Though the molecular mechanisms of NPC metastasis remain poorly understood, the functions of mitochondria that involved in 


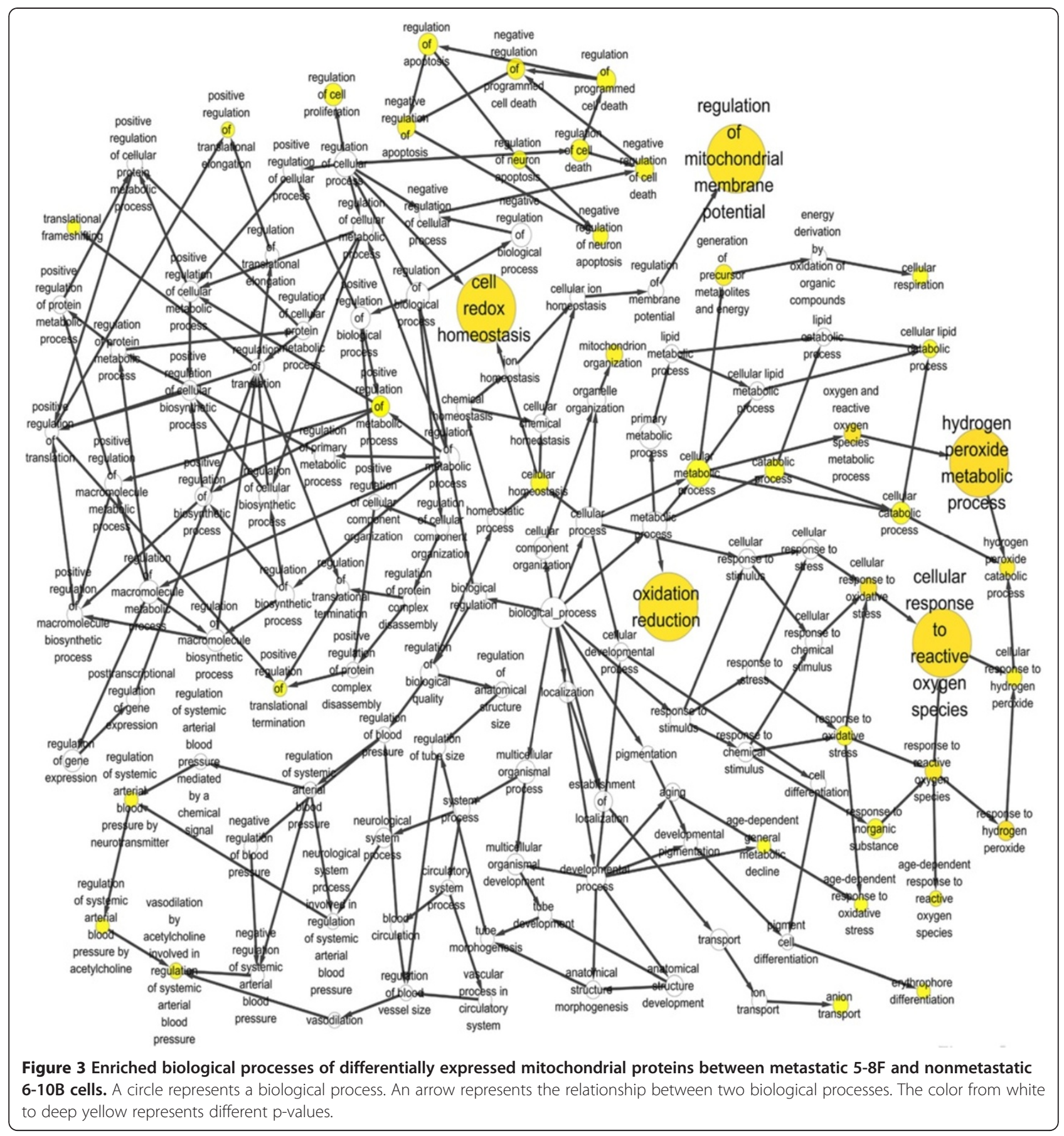

this process have been uncovered gradually: mitochondria are closely related to oxidative stress process in a cell. Different from the historical views, which assumed oxidative stress contributes to tumor initiation and progression solely by inducing genomic instability, the present views consider oxidative stress directly contributes to tumor metastasis. According to the tumorstroma co-evolution model, cancer cells induce oxidative stress in adjacent stromal cells and result in an excess production of ROS in mitochondria. Excess stromal ROS induces cytoskeleton rearrangements, autophagy, and mitophagy in the tumor microenvironment to help cancer cells escape excess ROS in the primary tumor site, also induces the stromal over-production of recycled nutrients such as ketones and L-lactate that are fuel for tumor growth and metastasis [10-16]. Moreover, the enhanced cellular antioxidant capability and antioxidant function of redox-signaling in cancer cells result in 


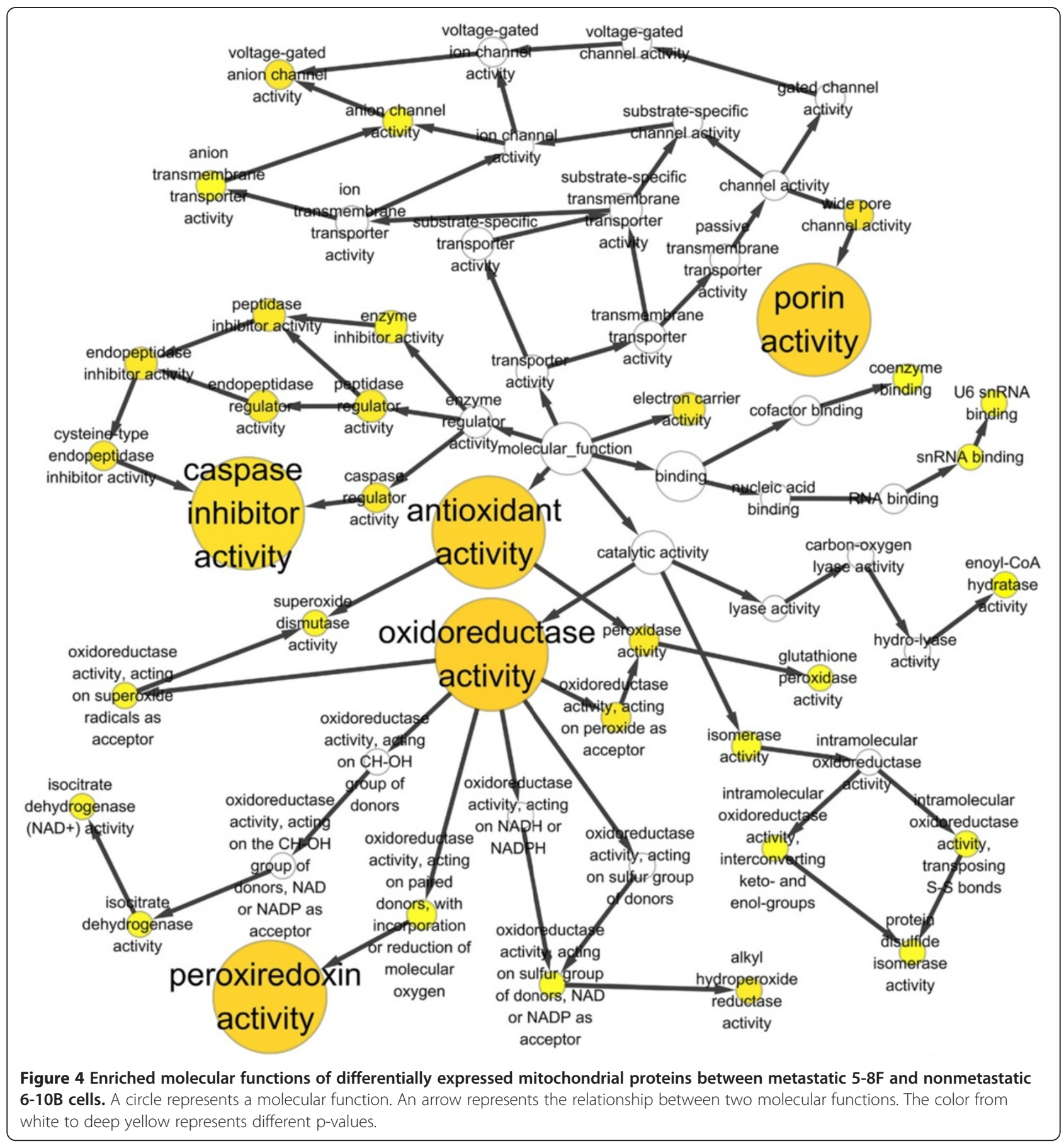

an increase of cell resistance to oxidant, defend cancer cells themselves from oxidative damage, and favor their metastasis [14].

In general the balance between ROS generation and elimination is delicately maintained in cells. However, for many cancer cells, an increase in ROS production or decrease in ROS-scavenger capacity disturbs redox homeostasis which leads to an overall increase of intracellular ROS level. Over-expressed catalase to alleviate mitochondrial oxidative stress in a mouse animal model of breast cancer could reduce metastatic tumor burden by $>12$-fold [13]. Considered this catalase experimental result and our PRDX3 study, it is very likely that a molecular network based on redox-signaling pathways in cancer cells directly contributes to tumor metastasis, this process relates closely to mitochondrial oxidative stress and ROS produced by mitochondria might play an important role in tumorigenesis (its direct action on 


\begin{tabular}{|c|c|c|c|}
\hline GO-ID & Description & P-Value & Genes \\
\hline \multicolumn{4}{|c|}{ Biological Process } \\
\hline 34614 & Cellular response to reactive oxygen species & 7.09E-6 & 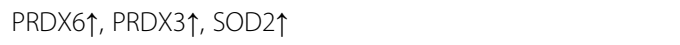 \\
\hline 42743 & Hydrogen peroxide metabolic process & $2.39 \mathrm{E}-6$ & 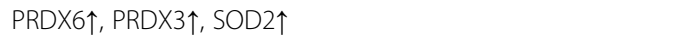 \\
\hline 51881 & Regulation of mitochondria membrane potential & $5.62 \mathrm{E}-5$ & $\mathrm{PRDX} 3 \uparrow, \mathrm{SOD} 2 \uparrow$ \\
\hline 45454 & Cell redox homeostasis & $3.92 \mathrm{E}-5$ & 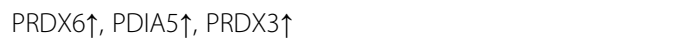 \\
\hline 55114 & Oxidation reduction & $2.92 \mathrm{E}-5$ & 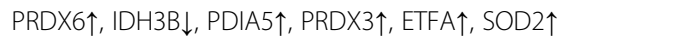 \\
\hline \multicolumn{4}{|c|}{ Molecular Function } \\
\hline 16491 & Oxidoreductase activity & 2.64E-6 & 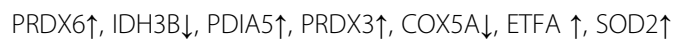 \\
\hline 43027 & Caspase inhibitor activity & $6.61 \mathrm{E}-5$ & 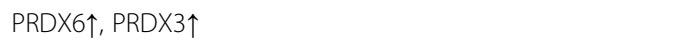 \\
\hline 51920 & Peroxiredoxin activity & $1.51 \mathrm{E}-5$ & PRDX6个, PRDX3个 \\
\hline 15288 & Porin activity & $1.51 \mathrm{E}-5$ & $\operatorname{VDAC} 2 \uparrow, \mathrm{VDAC} 1 \uparrow$ \\
\hline 16209 & Antioxidant activity & $1.35 \mathrm{E}-5$ & PRDX6个, PRDX3个, SOD $2 \uparrow$ \\
\hline
\end{tabular}

$\uparrow:$ up- regulated expression in metastatic 5-8F cells relative to non-metastatic 6-10B cells.

$\downarrow$ : down-regulated expression in metastatic $5-8 \mathrm{~F}$ cells relative to non-metastaic $6-10 \mathrm{~B}$ cells.

growth factors and transcription factors) and tumor metastasis as well.

Each mitochondrial DEP was rationalized in the tumor-stroma co-evolution model, and an experimental data-based diagram was proposed (Figure 9). In our comparative proteomic study of mitochondria between NPC metastatic 5-8F and nonmetastatic 6-10B cells, the first five enriched GO terms of DEPs were closely related to oxidative stress (Table 2). For PRDX3, our comparative proteomic data demonstrated the expression of PRDX3 in mitochondria of metastatic 5-8F cells is higher than in mitochondria of nonmetastatic 6-10B cells, it shows that the anti-oxidative stress capability in metastatic 5-8F cells is stronger than nonmetastatic 6$10 \mathrm{~B}$ cells. This result is consistent with previous conclusion [14] that the enhanced anti-oxidant capabilities in cancer cells defend themselves from excess stromal oxidative damage and favors cell metastasis. Furthermore, among several DEPs (data not showed) selected to carry out siRNA transient transfections and then Transwell Migration assay, only suppression of PRDX3 expression resulted in the significantly increased number of cells migrated through Transwell membrane $(\mathrm{P}<0.05)$. PRDX3, mitochondria thioredoxin-dependent peroxide reductase, is the main way by which cancer cells reduce their levels of $\mathrm{H}_{2} \mathrm{O}_{2}$ built up during active respiration $[17,18]$, suppression of this enzyme, a scavenger of peroxide, could increase oxidative stress in cancer cells to up-regulate the redox-signaling, promote the glycolysis, proliferation, and survival, and finally lead increased cells mobility potential [14] (Figure 8). To our knowledge, this was the first experimental evidence that PRDX3 was related to NPC metastasis.
PRDX6 increased about 2.5-fold in mitochondria of metastatic $5-8 \mathrm{~F}$ cells than in mitochondria of nonmetastatic $6-10 \mathrm{~B}$ cells. This result was consistent with the results of other research groups: PRDX6 expressions were increased in node-positive breast carcinoma samples compared with node-negative breast carcinoma samples [19]; enzymatic activities of PRDX6 in lung cancer cells metastasis [20]; over-expression of PRDX6 led to a more invasive phenotype and metastatic potential in human breast cancer [21]. Over-expression of PRDX6 is on the one hand to strengthen the peroxidase activity of a cell to reduce peroxidants such as $\mathrm{H}_{2} \mathrm{O}_{2}$ and hydroperoxides for the relief of oxidative stress. Besides of its peroxidase activity, PRDX6 has additional phospholipase A2 (PLA2) activity, this activity promotes accumulation of arochidonic acid, which, in turn, induces the invasive pathway involving p38 kinase, phosphoinositide 3-kinase, Akt and urokinase-type plasminogen activator. Over-expression of PRDX6 leads to a more invasive phenotype and metastasis potential, at least in part, through regulation of the levels of UPAR, Ets-1, MMP-9, RhoC, and TIMP-2 expression [20,21]. Therefore, PRDX6 in NPC metastatic process demonstrates a double-side effect. To our knowledge this was the first report of the relationship between PRDX6 and NPC metastasis.

SOD2 increased in many tumor types as they progress from early stage non-invasive disease to late stage metastatic disease, and its over-expression in many instances enhance the metastasis phenotype because SOD2 is able to catalize toxic oxidant $\mathrm{O}_{2}^{-}$into another toxic oxidant $\mathrm{H}_{2} \mathrm{O}_{2}$ and hydroperoxides, and $\mathrm{O}_{2}^{-}$and $\mathrm{H}_{2} \mathrm{O}_{2}$ / hydroperoxides both directly contribute to oxidative stress. 


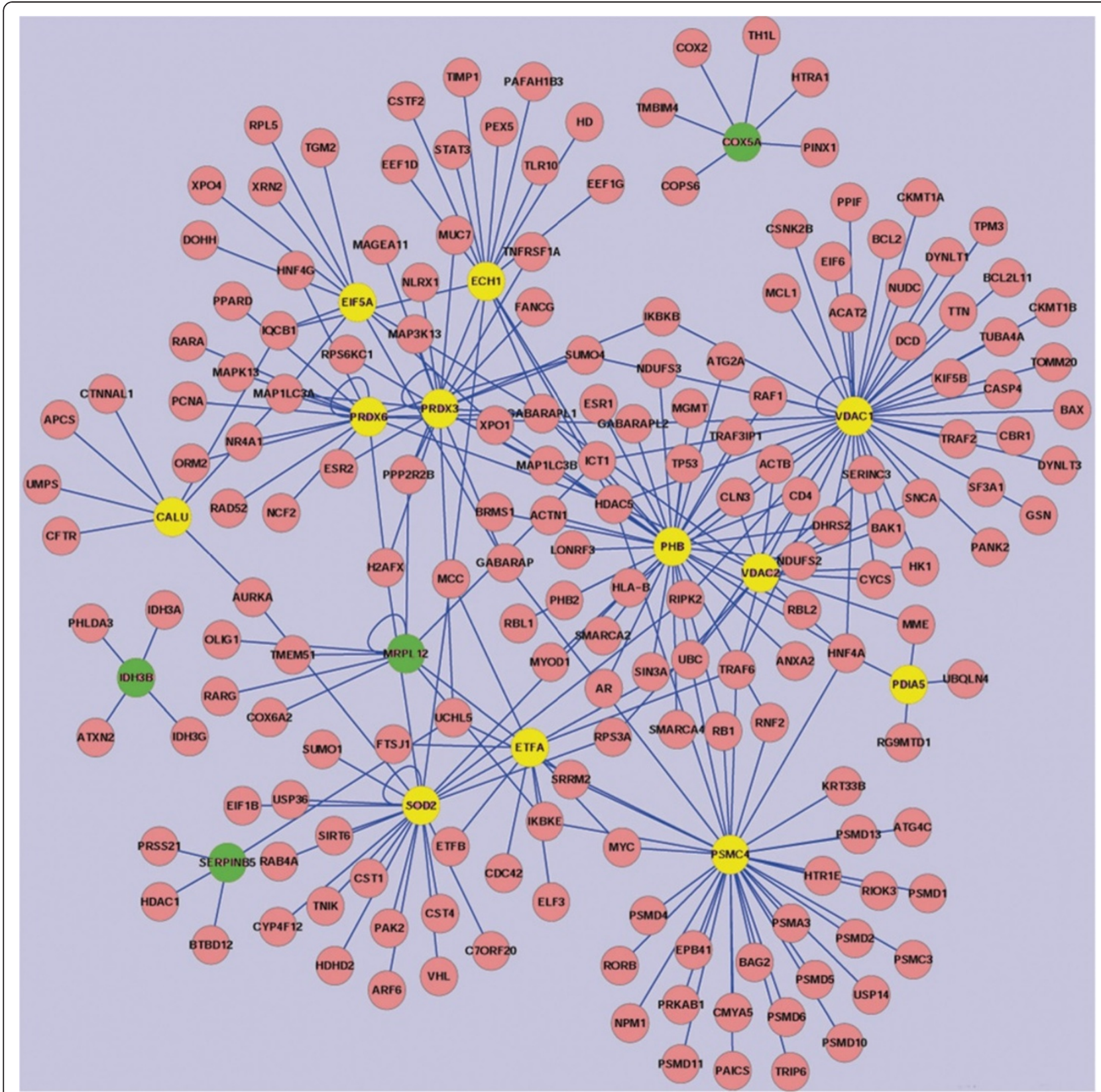

Figure 5 A protein-protein interaction sub-network of differentially expressed mitochondrial proteins between metastatic $5-8 \mathrm{~F}$ and nonmetastatic 6-10B cells. It contains 193 nodes (red, green and yellow circles) and 252 edges (blue lines). A green circle means a down-regulated protein in metastatic 5-8F cells relative to nonmetastatic 6-10B cells. A yellow circle means an up-regulated protein in metastatic $5-8 \mathrm{~F}$ cells relative to nonmetastatic $6-10 \mathrm{~B}$ cells.

However, this metastatic phenotype can be reversed by efficient $\mathrm{H}_{2} \mathrm{O}_{2}$ scavenging [22-26]. Our proteomic results also showed that SOD2 increased about 3.3-fold in mitochondria of metastatic $5-8 \mathrm{~F}$ than in nonmetastatic $6-10 \mathrm{~B}$ cells. To our knowledge this was the first report of the relationship between SOD2 and NPC metastasis.

Over-expression of ECH1 can enhance the energy generation, and promote adhension and migration capability of cancer cell for cancer metastasis. The present experimental data showed that ECH1 increased in 4.1fold in mitochondria of NPC metastatic $5-8 \mathrm{~F}$ than nonmetastatic $6-10 \mathrm{~B}$ cells. This result was consistent with the other studies [27], a higher expression level of ECH1 was confirmed in tissue from patients with gastric carcinoma with lymph node metastases, and downregulation of ECH1 could inhibit tumor proliferation, increase the ratio in S phase to G1 phase and decrease the adhesion and migration capacity. 


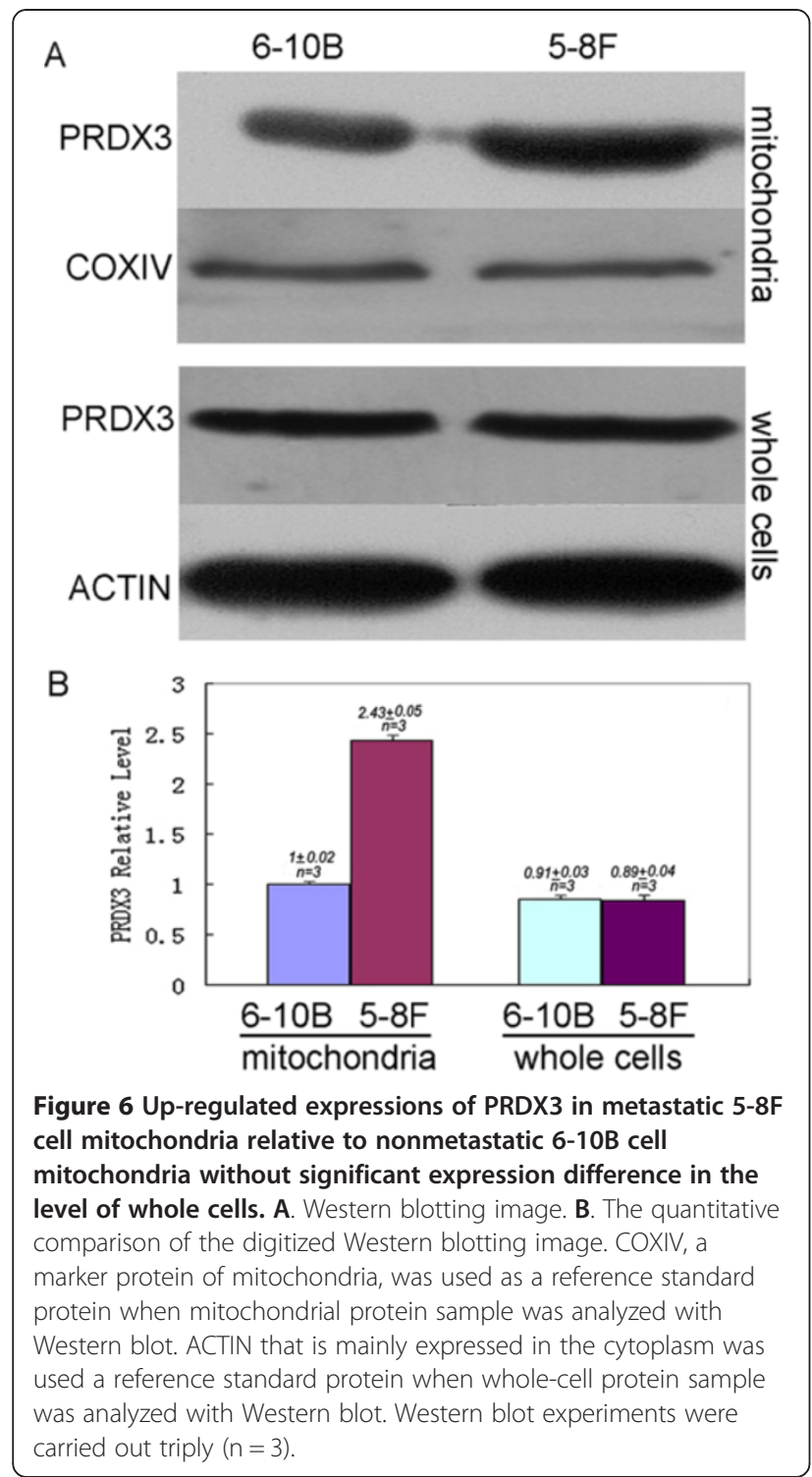

Studies [28] showed over-expression of each SERPINB gene could effectively suppress the invasiveness and motility of malignant cancer cells. Nuclear localization of SERPINB5 is required for its tumor metastasis suppressor function and it was enriched at the promoter of colony-stimulating factor (CSF-1) in chromatin immunoprecipitation and associated with diminished levels of CSF-1 mRNA. It suggests that its mechanism of action involves, in part, direct association of SERPINB5 with target genes to inhibit metastatic phenotype [29]. The present studies showed a down-regulation of SERPINB5 by 3.2 -fold in mitochondria of NPC metastatic $5-8 \mathrm{~F}$ than nonmetastatic 6-10B cells. Thus, the down-regulated SERPINB5 might enhance the metastatic capability of an NPC cancer cell.

COX subunit composition is regulated by COX5A and COX5B gene transcription in response to high and low
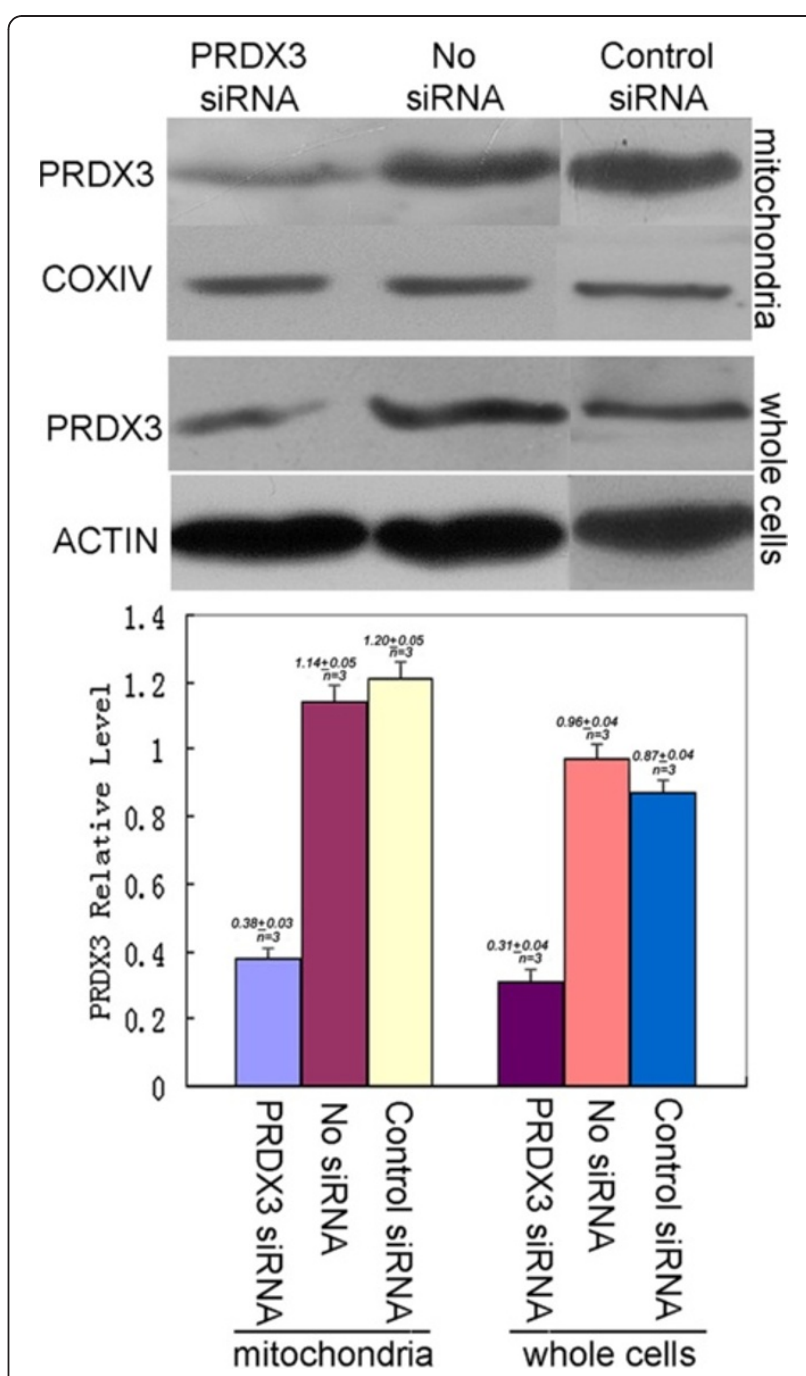

Figure 7 Effects of PRDX3 siRNA transient transfection on the PRDX3 expression of metastatic 5-8F cells. Suppression of PRDX3 expression in the levels of mitochondria and whole cells of the metastatic 5-8F cells treated with siRNA relative to without siRNA and control siRNA treatments. The top shows the Western blotting image. The bottom shows the quantitative comparison of the digitized Western blotting image. COXIV, a marker protein of mitochondria, was used as a reference standard protein when mitochondrial protein sample was analyzed with Western blot. ACTIN that is mainly expressed in the cytoplasm was used a reference standard protein when whole-cell protein sample was analyzed with Western blot. Western blot experiments were carried out triply $(n=3)$.

$\mathrm{O}_{2}$, respectively. This subunit switch maintains mitochondria redox homeostasis and relates to morphological and functional alteration of mitochondria [30]. PDIA5 also directly involves in the redox homeostasis. The present studies demonstrate that the downregulation of COX5A and up-regulation of PDIA5 in NPC metastatic 5-8F cells relative to nonmetastatic 6$10 \mathrm{~B}$ cells. The abnormal expression of COX5A and 

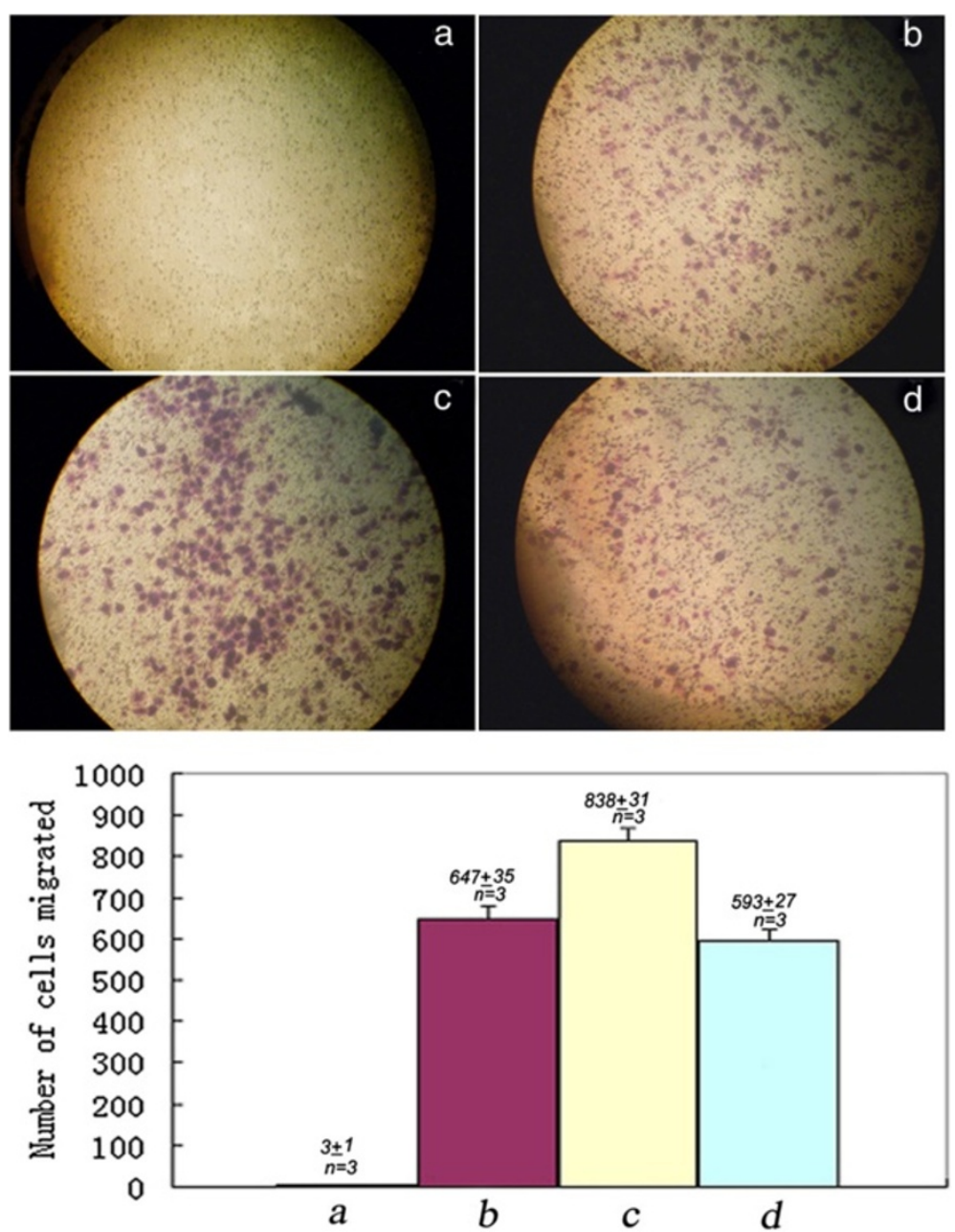

Figure 8 Effects of PRDX3 siRNA transient transfection on the migration capability of metastatic 5-8F cells. Effect of PRDX3 siRNA transient transfection on migration capability of metastatic $5-8 \mathrm{~F}$ cells. The top shows four representative micrographs of metastatic 5-8F cells migrated through Transwell insert membranes among four experimental groups (400 $\times$ ). The bottom shows the quantitative comparison of the number of cells that migrated through Transwell insert membranes. Group A (a): nonmetastatic 6-10B cells. Group B (b): metastatic 5-8F cells. Group C (c): metastatic 5-8F cells with PRDX3 siRNA transient transfection. Group D (d): metastatic 5-8F cells with a scramble sequence siRNA transient transfection. Transwell migration assays were carried out triply $(n=3)$.

PDIA5 in NPC metastatic 5-8F cells might disturb the redox homeostasis to contribute to its metastatic process.

Studies [31] demonstrated over-expression of EIF5A enhances cell motility and promotes tumor metastasis in hepatocellular carcinoma. It was able to induce epithelial-mensenchymal transition (EMT), a key event in tumor invasion and metastasis, characterized by down-regulation of epithelial markers (E-cadherin and beta-catenin) and up-regulation of mesenchymal markers (fibronectin, N-cadherin, alpha-SMA and vimentin). It could also stimulate cytoskeleton rearrangement through activation of RhoA/Rac1 to contribute to the cancer cell metastasis. The present data showed EIF5A increased 2.5-fold in mitochondria of NPC metastatic 5-
$8 \mathrm{~F}$ than nonmetastatic $6-10 \mathrm{~B}$ cells. It suggests that overexpressed EIF5A contributes to NPC cancer cell metastasis.

IDH3B [32] involves in the mitochondrial tricarboxylic acid cycle that is initiated by acetyl-CoA. Acetyl-CoA is derived from the travel of pyruvic acid from cytoplasm into the interior of the mitochondrion. Pyruvic acid is generated from the glycolysis of glucose. The current study demonstrated the down-regulation of mitochondrial IDH3B in NPC metastatic 5-8F cells. Downregulated IDH3B will obstacle the tricarboxylic acid cycle to reduce the generation of ATP, cause energy metabolism obstacle and mitochondrial dysfunction, and promote oxidative stress. Meanwhile, the tricarboxylic acid cycle obstacle will built up the pyruvic acid. Studies 


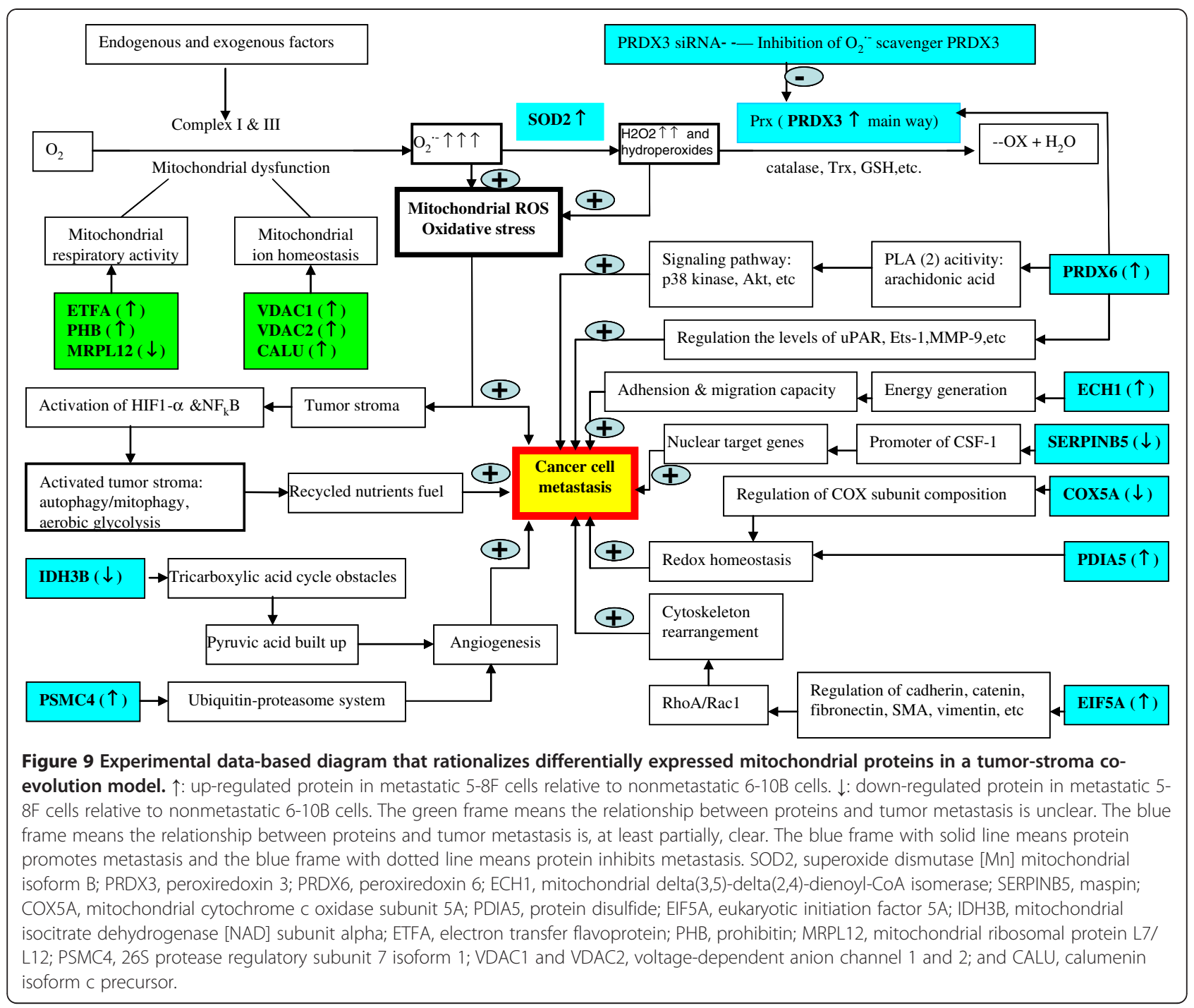

[33] demonstrated that pyruvic acid has strong angiogenic activity and plays an important role in angiogenesis for tumor growth and metastasis.

PSMC4 is a $26 \mathrm{~S}$ protease that is involved in the ATPdependent degradation of ubiquitinated proteins in the ubiquitin-proteasome system (UPS) that is extensively associated cancer pathogenesis [34]. The UPS plays a central role in fine-tuning the functions of core proangiogenic proteins including VEGF, VEGFR-2, angiogenic signaling proteins such as the PLCy1 and PI3 kinase/ AKT pathways, and other non-VEGF angiogenic pathways to regulate the tumor angiogenesis [35]. The up-regulation of PSMC4 would contribute to this angiogenesis process for tumor metastasis.

Moreover, ETFA is a mitochondrial electron transfer flavoprotein [36]. The ETFA up-regulation in NPC metastatic cell could promote mitochondrial electron transport and oxidative phosphorylation, and enhance mitochondrial oxidative stress. Prohibitin (PHB) is a pro-oncogene, inhibits DNA synthesis, and regulates proliferation. However, PHB gene mutated in human cancers [37], PHB protein responds to mitochondrial stress and may play a role in regulating mitochondrial respiration activity [38]. MRPL12 may act as a scaffolding protein or stabilizer of respiratory chain supercomplexes, is involved in regulation of mitochondrial protein translation and respiration, and plays a role in mitochondrial-mediated death. The current studies found down-regulation of MRPL12, which would regulate mitochondria-mediated cell death and respiration $[39,40]$. VDAC1 and VDAC2 forms a channel through the mitochondrial outer membrane with a weak anion selectivity at the open state and a cation-selectivity at the close state $[41,42]$, and GALU is involved in the binding of calcium ions [43]. The current studies showed the up-regulated expression of VDAC1, VDAC2, and GALU, they would disturb the mitochondrial ion homeostasis in the mitochondrial dysfunction and 
oxidative stress. The relationship of those mitochondrial DEPs and the tumor metastasis needs to be validated with experiments; however, these data are novel clues to insight into the mechanisms of NPC metastasis.

\section{Conclusions}

In summary, the present study provides new insights for exploring the significance of mitochondria and oxidative stress in NPC metastatic processes. Ten mitochondrial DEPs including PRDX3, PRDX6, SOD2, ECH1, SERPINB5, COX5A, PDIA5, EIF5A, IDH3B, and PSMC4 have been rationalized in the tumor-stroma co-evolution model that mitochondrial oxidative stress directly contributes to tumor metastasis (Figure 9). The expression suppression of mitochondrial PRDX3 protein in the anti-oxidative stress system enhanced the mobility potential of NPC metastatic cancer cells, which consolidates the roles of mitochondrial oxidative stress in NPC metastasis. Further investigation is required to determine the biological consequences of all identified mitochondrial DEPs and their relevance to the pathogenic mechanisms of NPC metastasis.

\section{Methods}

\section{Materials}

All primary and secondary antibodies, siRNA duplex and a scrambled sequence control siRNA were from Santa Cruz. Lipofectamine ${ }^{\text {TM }}$ RNAiMAX transfection reagents and serum-free medium were from Invitrogen. Immobiline DryStrip gels (pH 3-10 NL, $24 \mathrm{~cm}$ ), CyDye DIGE fluor Cy2, Cy3 and Cy5 were from GE Healthcare. Matrigel basement membrane matrix was from BD Biosciences. Transwell plates and inserts (Cat. No. 3422) were from Corning. All other chemicals, unless stated otherwise, were obtained from Sigma.

\section{Cells culture}

NPC 5-8F and 6-10B cells were obtained from the Modern Analytical Testing Center of Central South University of China. Cells were cultured in RPMI 1640 medium supplemented with $10 \%$ fetal bovine serum (FBS) and antibiotics in a humidified incubator with $5 \% \mathrm{CO}_{2}$ in air at $37^{\circ} \mathrm{C}$. The cells were grown to $80 \%$ confluence, washed twice with D-Hank's solution, digested with $0.25 \%$ trypsin and $0.02 \%$ ethylenediaminetetraacetate dehydrate (EDTA), collected by centrifugation $\left(400 \times \mathrm{g}, 10 \mathrm{~min}, 4^{\circ} \mathrm{C}\right)$. A total of $\sim 2 \times 10^{7}$ cells were needed for experiments.

\section{Preparation and characterization of mitochondria, and extraction of mitochondrial proteins}

Mitochondria were isolated from $5-8 \mathrm{~F}$ and $6-10 \mathrm{~B}$ cells, respectively, according to the Sucrose Gradient Separation Manual (www.mitosciences.com) with a minor modification. Briefly, the collected cells described above were resuspended in five volumes of Mito buffers $(0.25 \mathrm{M}$ sucrose, $1 \mathrm{mM}$ EDTA, $10 \mathrm{mM}$ Tris. $\mathrm{HCl} \mathrm{pH}$ 7.4, $1 \mathrm{mM}$ phenylmethanesulfonyl fluoride (PMSF), $1 \mathrm{mg} / \mathrm{ml}$ leupeptin, $1 \mathrm{mg} / \mathrm{ml}$ pepstatin) and homogenized by pre-cooled Potter-Elvehjem homogenizer $(1,000 \mathrm{rpm}$; around 20 up and down strokes). The homogenates were centrifuged $\left(1,000 \times \mathrm{g}, 10 \mathrm{~min}, 4^{\circ} \mathrm{C}\right)$ to collect the supernatants. The supernatants were centrifuged $\left(12,000 \times \mathrm{g}, 15 \mathrm{~min}, 4^{\circ} \mathrm{C}\right)$ to collect the pellets. The pellets were resuspended in $0.5 \mathrm{ml}$ Mito buffers. The discontinuous sucrose gradient separation solutions were prepared in centrifuge tubes with gradient from bottom to top that is $0.5 \mathrm{ml}$ of $2.0 \mathrm{M}$ sucrose, $1 \mathrm{ml}$ of $1.3 \mathrm{M}$ sucrose, $1 \mathrm{ml}$ of $1.0 \mathrm{M}$ sucrose, and $0.5 \mathrm{ml}$ of $0.8 \mathrm{M}$ sucrose. The resuspended samples were carefully applied to the top of gradient solutions and centrifuged $\left(80,000 \times \mathrm{g}, 2 \mathrm{~h}, 4^{\circ} \mathrm{C}\right.$; Beckman swinging bucket $55 \mathrm{Ti}$ rotors). The brown belts between $1.0 \mathrm{M}$ and 1.3 M sucrose layers were collected carefully with a $5-\mathrm{ml}$ syringe needle immediately after centrifugation. A volume $(600 \mu \mathrm{l})$ of methanol was added to the top of $150 \mu \mathrm{l}$ brown sucrose solution, and mixed; then $150 \mu \mathrm{l}$ of chloroform and $450 \mu \mathrm{l}$ of water were added, mixed again, and centrifuged $\left(18,000 \times \mathrm{g}, 5 \mathrm{~min}, 4^{\circ} \mathrm{C}\right)$. All organic and inorganic liquids in centrifuge tubes were poured off carefully, followed by air dry at $4^{\circ} \mathrm{C}$ of the white discs of proteins. The white discs of proteins were solubilized $(2 \mathrm{~h}$; intermittent mix) in $800 \mu \mathrm{l}$ lysis buffer that contained $8 \mathrm{M}$ urea, $2 \mathrm{M}$ thiourea, $130 \mathrm{mM}$ dithiothreitol (DTT), 4\% 3-[(3-cholanidopropyl) dimethylammonio] -1-propanesulfonate (CHAPS), $40 \mathrm{mM}$ tris base, $1 \mathrm{mM}$ EDTA, $1 \mathrm{mM}$ PMSF, $1 \mathrm{mg} / \mathrm{ml}$ leupeptin, $1 \mathrm{mg} / \mathrm{ml}$ pepstatin, and $\mathrm{pH} 8.5$ adjusted by $50 \mathrm{mM} \mathrm{NaOH}$, and centrifuged $\left(18,000 \times \mathrm{g}, 2 \mathrm{~h}, 4^{\circ} \mathrm{C}\right)$. The supernatants were collected. The protein concentration of the supernatants was determined by a 2-D Quantification kit (GE Healthcare). The isolated mitochondria were characterized according to Murayama's method [44]. Briefly, the extracted mitochondrial proteins were separated by $12 \%$ sodium dodecyl sulfate polyacrylamide gel electrophoresis (SDS-PAGE) gels, transferred to polyvinylidene fluoride (PVDF) membranes (Semi-dry Nova blot, Pharmacia Biotech), probed with various primary antibodies against marker proteins from different cellular compartments (LDH, PCNA, COX IV, catalase, GRP 78, and cathepsin D) and corresponding secondary antibodies, and visualized by a SuperSingal West Pico ECL kit (Thermo). Preparation of isolated mitochondria for electron microscopic observation was carried out according to the related manual and observation was made by a Hitachi $\mathrm{H} 7500$ transmission electron microscope.

\section{D-DIGE and imaging analyses}

The 2D-DIGE experimental flow-chart was shown (Figure 10). Briefly, Mitochondrial proteins were labeled 


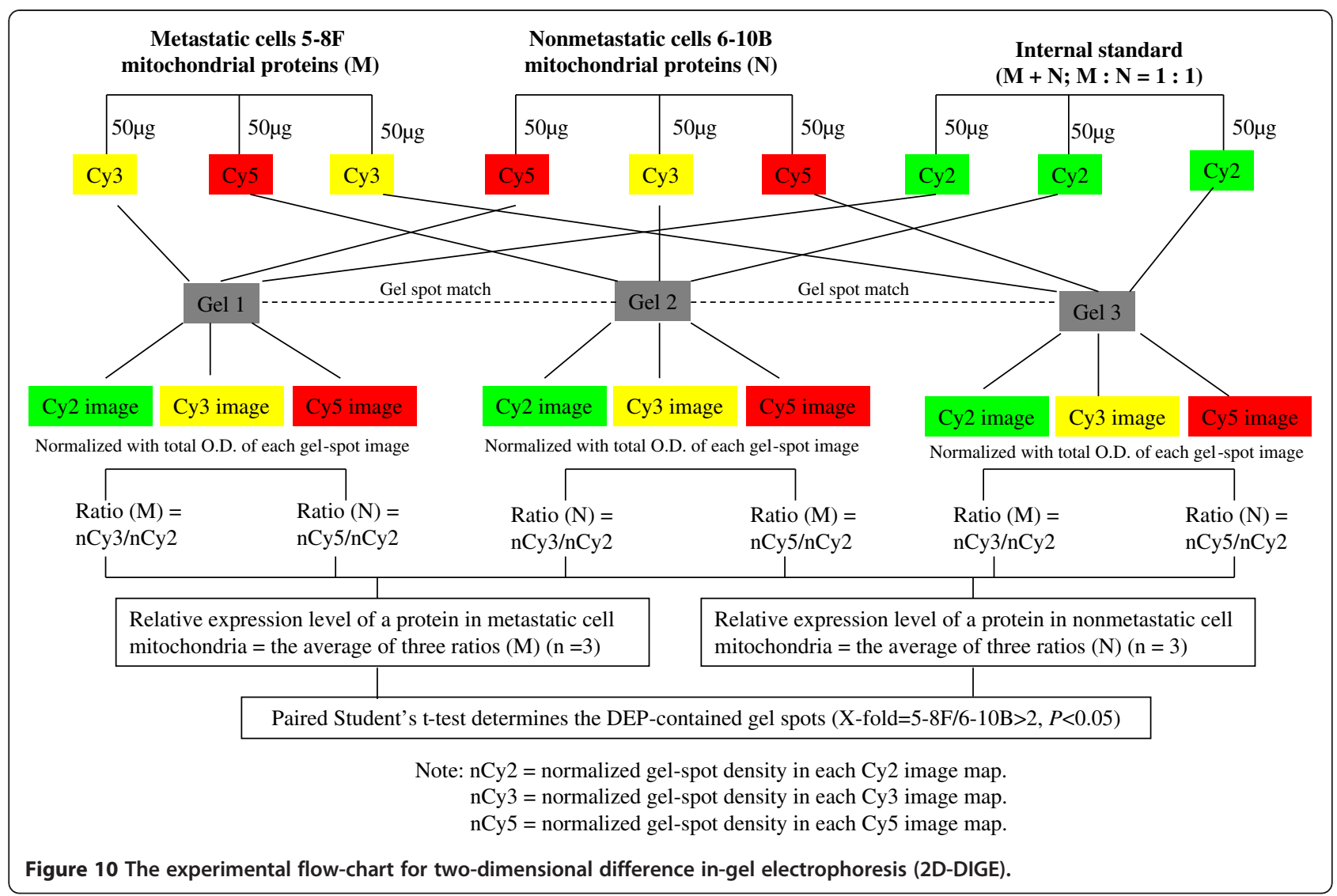

with fluorescent cyanine dyes following the Instruction of Amersham CyDye DIGE Fluors (minimal dyes) for Ettan DIGE Product Booklet. An amount $(50 \mu \mathrm{g})$ of proteins were labeled with $400 \mathrm{pmol}$ of dyes (dark; on ice; $30 \mathrm{~min}$ ) and then quenched (10 min) with $1 \mu \mathrm{l}$ of $10 \mathrm{mM}$ lysine. Two sets of metastatic 5-8F cell proteins were labeled with $\mathrm{Cy} 3$ and the third set with Cy5. Two sets of nonmetastatic 6-10B cell proteins were labeled with Cy5 and the third set with Cy3. Each set of above sample contained $50 \mu \mathrm{g}$ proteins. The internal standard $(75 \mu \mathrm{g}$ of metastatic $5-8 \mathrm{~F}$ cell proteins plus $75 \mu \mathrm{g}$ of nonmetastatic 6-10B cell proteins) was labeled with Cy2. One set $(50 \mu \mathrm{g})$ of Cy3-labeled proteins was combined with one set $(50 \mu \mathrm{g})$ of Cy5-labeled proteins and combined again with one third $(50 \mu \mathrm{g})$ of Cy2-labeled internal standard proteins. The combined sample was added in equal volume of $2 \times$ sample buffer ( 8 M urea, $130 \mathrm{mM}$ DTT, $4 \%$ CHAPS, and 2\% Pharmalyte 3-10), and then supplied with rehydration buffer (8 M urea, $130 \mathrm{mM}$ DTT, 4\% CHAPS, and $1 \%$ pharmalyte 3-10) to the total volume of $450 \mu \mathrm{l}$. The mixed sample $(450 \mu \mathrm{l})$ was applied to an immobiline DryStrip gel; and three analytic gels and one preparative gel were simultaneously focused on an IPGphor Unit (GH Healthcare) with a total of 80,000 Vhr. The focused proteins in the immobiline DryStrips were equilibrated in a solution containing $65 \mathrm{mM}$ DTT
(15 min), and in another solution containing $135 \mathrm{mM}$ iodacetamide $(15 \mathrm{~min})$. The equilibrated proteins in the immobiline DryStrip were separated by $12.5 \%$ SDSPAGE gels in an Ettan DALT II system (GE Healthcare). After electrophoresis, each gel was scanned on a Typhoon 9410 scanner (GE Healthcare) at appropriate wavelengths that were specific for Cy2 $(488 / 520 \mathrm{~nm})$, Cy3 $(532 / 580 \mathrm{~nm})$, and Cy5 $(633 / 670 \mathrm{~nm})$. In total 9 protein-spot image maps were generated. Each gel-spot density was normalized by the total density in each protein-spot image map. The DeCyder differential in-gel analysis (DIA) module was used for pair-wise comparison of each $5-8 \mathrm{~F}$ and $6-10 \mathrm{~B}$ protein to the internal standard in each gel. The DeCyder biological variation analysis (BVA) module was then used to simultaneously match all 9 protein-spot image maps. The normalized Cy3/normalized Cy2 and normalized Cy5/normalized Cy2 DIA ratios were used to calculate average abundance changes. The average of three DIA ratios from metastatic cell 5-8F mitochondria represents the relative expression level of a protein in metastatic cell mitochondria, and the average of three DIA ratios from nonmetastatic cell 6-10B mitochondria represents the relative expression level of a protein in nonmetastatic cell mitochondria. The paired Student's t-test p-values were used for the variance of these ratios for each protein pair across all samples (all 9 
protein-spot image maps) to determine each DEPcontained gel-spot. Each DEP-contained gel-spot was excised for protein identification.

\section{MS-identification of mitochondrial DEPs}

The 2D gel spots that contained DEPs were excised from the preparative gels. The proteins in the gel-spot were destained, reducted, alkylated, and digested in gels with trypsin [45]. For PMF analysis, the tryptic peptides were eluted from ZipTips with $80 \%$ acetonitrile/0.1\% trifluoroacetic acid, and were spotted onto a MALDI target with an equal volume of cyano-4-hydroxycinnamic acid $(10 \mathrm{mg} / \mathrm{ml}$; Sigma) saturated with $50 \%$ acetonitrile in $0.05 \%$ TFA. The mass spectrometric (MS) spectra were acquired on a Voyager DE STR MALDI-TOF mass spectrometer (ABI, Foster City, CA). The instrument settings were reflector mode with 160-ns delay extraction time, positive polarity, and $20-\mathrm{kV}$ accelerating voltage. The spectrum mass-tocharge $(\mathrm{m} / \mathrm{z})$ were usually acquired with laser shots at 200/spectrum and ranged from 1000 to $4000 \mathrm{~m} / \mathrm{z}$. External calibration was performed using a Peptide Mass Standard kit (Perspective Biosystems, Framingham, MA). The acquired MS spectra were processed with base-line correction, noise removal (5\%), and peak deisotoping using DataExplore (Version 4.0.0.0) software to generate the peaklist for peptide mass fingerprint (PMF) analysis. The PMF data were input into Mascot (www.matrixscience.com/) for protein identity searching. The PMF data from the Voyager DE STR mass spectrometer were searched against the NCBInr database (release date January 7, 2012; 16,831,682 sequences, 5,781,564,572 residues; Homo sapiens 241,934 sequences). The search was restricted to "Human" as taxonomy. The other search parameters included type of search (peptide mass fingerprint), enzyme (trypsin), fixed modifications (carbamidomethylcysteine), variable modifications (methionine oxidation), mass values (monoisotopic), protein mass (unrestricted), peptide mass tolerance $(100 \mathrm{ppm})$, peptide charge state $(1+)$, and 1 maximum missed cleavages. Proteins whose scores were greater than 66 were considered as significance $(\mathrm{p}<0.05)$, and only human proteins with the best score in each Mascot search were accepted as successful identifications. The coverage of amino acid sequence, the Mascot score, the mass and pI, and accession number are obtained for each protein.

Proteins in a 2D gel spot that was not identified or was a mixture identified by MALDI-TOF PMF data were subjected to electrospray ionization (ESI)-quadrople (Q)TOF MS/MS analysis. Briefly, the tryptic peptides from 2D gel spots were loaded onto a C18 pre-column for concentrations and fast desalting, and then eluted to the reversed-phase column for separation. MS/MS spectra were performed in data-depended mode in which up to four precursor ions above an intensity threshold of 7 counts/seconds (cps) were selected for MS/MS analysis from each survey scan. For MS/MS database query, the peptide sequence tag (PKL) format file that was generated from MS/MS data with MassLynx v 4.0 software were inputted into the Mascot search engine to search protein against the NCBInr database (release date January 7, 2012; 16,831,682 sequences, 5,781,564,572 residues; Homo sapiens 241,934 sequences). A mass tolerance of 0.3 Da for both parent (MS) and fragmented (MS/MS) ions, allowance for up to one trypsin miscleavage, variable amino acid modifications consisting of methionine oxidation and cysteine carbamidomethylation were used. MS/MS ion score threshold was determined to produce a false-positive rate less than $5 \%$ for a significant hit $(\mathrm{P}<0.05)$. The false-positive rate was calculated with $2 *$ reverse/(reverse + forward)/100. In the current study, the MS/MS ion score threshold was 45 and a falsepositive rate was approximately $3.1 \%$. Only protein IDH3B was identified with only one peptide with a Mascot score of 73, its MS/MS spectrum was further checked manually and interpreted with de-novo sequencing.

\section{Functional enrichment analyses of mitochondrial DEPs and protein-protein interaction data}

The gene names of mitochondrial DEPs were converted to NCBI-Entrez format for consistency and saved as a text file that was inputted into Cytoscape v 2.8.2 (www. cytoscape.org), and BiNGO plugin 2.44 downloaded from Cytoscape manage plugin was used to analyze the enriched biological processes and molecular functions. Human protein-protein interaction data that were downloaded from HPRD (release 9; www.hprd.org) and NCBI databases (www.ncbi.nlm.nih.gov) were used to generate a protein-protein interaction sub-network of mitochondrial DEPs; the result only extended one layer connection and could be visualized by Cytoscape.

\section{siRNA transient transfection}

The siRNA transient transfections of metastatic 5-8F cells were conducted according to siRNA Transfection Protocols (Santa Cruz) and Transfection Technology Protocols (Invitrogen) with a minor modification. Briefly, the cells were incubated in a six wells plate (Costar) at $37^{\circ} \mathrm{C}$ in a $\mathrm{CO}_{2}$ incubator till $70-80 \%$ confluence. The solution $\mathrm{A}(2.4 \mu \mathrm{l}$ RNAiMAX in $100 \mu \mathrm{l}$ serum-free medium) and solution B $(10 \mu \mathrm{l}$ siRNAs duplex in $100 \mu \mathrm{l}$ serum-free medium) were mixed gently (the final concentration in each well was $100 \mathrm{nM}$ ), and incubated (room temperature; $45 \mathrm{~min}$ ). Cells were washed twice with serum-free medium, and then added into $200 \mu \mathrm{l}$ of above $\mathrm{A}+\mathrm{B}$ mixture and $800 \mu \mathrm{l}$ of serum-free medium in each well. After cells were incubated $(7 \mathrm{~h})$, the medium in each well were removed and replaced with 
$2.5 \mathrm{ml}$ normal fresh growth medium, cells were continued to be incubated $(48 \mathrm{~h})$. Cells were washed twice with D-Hank's solution, digested with $0.25 \%$ trypsin and $0.02 \%$ EDTA, collected by centrifugation $(400 \times$ g; $10 \mathrm{~min} ; 4^{\circ} \mathrm{C}$ ). A scrambled sequence control siRNA experiment was conducted at the same time. The efficiency of siRNA transfection was tested by Western blotting.

\section{Transwell Migration assays}

Cells Transwell Migration assay was carried out according to Matrigel Basement Membrane Matrix Product Specification Sheet (BD Biosciences) and Transwell Insert Product Description (Corning) with a minor modification. Briefly, the Matrigel basement membrane matrix was thawed $\left(4^{\circ} \mathrm{C}\right.$; overnight), the Transwell plates was put and inserted (both were added with serum-free medium) in a $\mathrm{CO}_{2}$ incubator $\left(37^{\circ} \mathrm{C} ; 2 \mathrm{~h}\right)$. The medium in Transwell plates was removed and Transwell plates were inserted and kept on ice. Precooled pipettes were used to add $20 \mu \mathrm{l}$ Matrigel matrix (1:1 diluted with pre-cooled serum-free medium) into each compartment of Transwell inserts and swirled immediately to disperse materials evenly, placed Transwell inserts $\left(37^{\circ} \mathrm{C} ; 30 \mathrm{~min}\right)$ to form thin Matrigel. A volume $(600 \mu \mathrm{l})$ of medium (RPMI 1640 with 10\% FBS and $5 \mu \mathrm{g} / \mathrm{ml}$ fibronectin) was added to each Transwell plates well, followed by adding the above thin Matrigel inserts, then $200 \mu \mathrm{l}$ medium and the cells (resuspended cells in medium at a density of $5 \times 10^{4}$ cells $/ \mathrm{ml}$ ) were added into each compartment of thin Matrigel inserts, and incubated in a $\mathrm{CO}_{2}$ incubator $\left(37^{\circ} \mathrm{C} ; 24 \mathrm{~h}\right)$. All of these experiments should be carefully handled using sterile techniques. Those non-migrated cells on each compartment of thin Matrigel inserts were scraped off with cotton swabs, the migrated cells were fixed and stained by $0.1 \%$ crystal violet solution. The cells without siRNA transient transfection and with a scrambled sequence transfection were used as control groups. In three independent experiments, the number of cells that migrated through Transwell insert membrane was counted in 9 visual fields per well at $400 \times$ under an Olympus microscope, means of these counts were calculated for statistical analysis using SPSS software, and variables were compared using Student's t-test with a significance level of $\mathrm{P}=0.05$.

\section{Additional file}

Additional file 1: Figure 1. Protein spot 1. Figure 2. Protein spot 2 Figure 3. Protein spot 3. Figure 4. Protein spot 4. Figure 5. Protein spot 5. Figure 6. Protein spot 6. Figure 7. Protein spot 7. Figure 8. Protein spot 8. Figure 9. Protein spot 9. Figure 10. Protein spot 10. Figure 11. Protein spot 11. Figure 12. Protein spot 12. Figure13. Protein spot 13. Figure 14. Protein spot 14. Figure 15. Protein spot 15.

\section{Abbreviations}

CHAPS: 3-[(3-cholanidopropyl)dimethylammonio]-1-propanesulfonate; DEG: Differentially expressed gene; DEP: Differentially expressed protein; DTT: Dithiothreitol; EDTA: Ethylenediaminetetraacetate dehydrate; ESI: Electrospray ionization; GO: Gene ontology; MALDI: Matrix-assisted laser desorption ionization; MS: Mass spectrometry; MS/MS: Tandem mass spectrometry; NPC: Nasopharyngeal carcinoma; PMF: Peptide mass fingerprint; PMSF: Phenylmethanesulfonyl fluoride; PRDX3: Peroxiredoxin 3; ROS: Reactive oxygen species; 2D-DIGE: Two-dimensional difference in-gel electrophoresis; TOF: Time-of-flight.

\section{Competing interests}

The authors declare no competing interests.

\section{Authors' contributions}

Conception and design of experiments: JL, XZ and ZC. Development of methodology and acquisition of data: $J, M L, G L, P Z$ and $Z X$. Analysis and interpretation of data: $J L$ and XZ. Writing, review, and/or revision of manuscript: JL, XZ and ZC. Administrative, technical, or material support: MS, FP and RH. Study supervision: XZ and ZC. All authors read and approved the final manuscript

\section{Acknowledgements}

This work was supported by the National Basic Research Program of China (Grant No. 2011CB910704), the National Natural Science Foundation of China (Grant No. 30973289), and Xiangya Hospital Funds for Talent Introduction (X.Z.).

\section{Author details}

'Key Laboratory of Cancer Proteomics of Chinese Ministry of Health, Xiangya Hospital, Central South University, 87 Xiangya Road, Changsha, Hunan 410008 , P.R. China. ${ }^{2}$ Hunan Engineering Laboratory for Structural Biology and Drug Design, Xiangya Hospital, Central South University, 87 Xiangya Road, Changsha, Hunan 410008 , P.R. China. ${ }^{3}$ Cancer Research Institute, Xiangya School of Medicine, Central South University, 88 Xiangya Road, Changsha, Hunan 410078, P.R. China. ${ }^{4}$ Bio-Analytical Chemistry Research Laboratory, Modern Analytical Testing Center, Central South University, 88 Xiangya Road, Changsha, Hunan 410078, P.R. China. ${ }^{5}$ Department of Biology, School of Pharmacy and Life Science, University of South China, Hengyang 421001, P.R. China.

Received: 14 August 2012 Accepted: 30 November 2012 Published: 6 December 2012

\section{References}

1. Wu YT, Wang HM, Yang XP, Li MZ, Chen J, Fang Y: Establishment and characterization of a xenografted nasopharyngeal carcinoma and eorresponding epitheliad cell line. Chinese J Cancer 1995, 14(2):83-86.

2. Song LB, Wang HM, Zheng MS, Li MZ, Jian SW: Study on the tumor heterogeneity of nasopharyngeal carcinoma cell line (SUNE-1). Chinese J Cancer 1998, 17(5):324-327.

3. Song LB, Yan J, Jian SW, Zhang L, Li MZ, Li D: Molecular mechanisms of tumorgenesis and metastasis in nasopharyngeal carcinoma cell sublines. Chinese J Cancer 2002, 21(2):158-162.

4. Yang XY, Ren CP, Wang L, Li H, Jiang CJ, Zhang HB: Identification of differentially expressed genes in metastatic and non-metastatic nasopharyngeal carcinoma cells by suppression subtractive hybridization. Cell Oncol 2005, 27(4):215-223.

5. Li J, Fan Y, Chen J, Yao KT, Huang ZX: Microarray analysis of differentially expressed genes between nasopharyngeal carcinoma cell lines $5-8 \mathrm{~F}$ and 6-10B. Cancer Genet Cytogenet 2010, 196(1):23-30.

6. Xiang YL, Yi H, Li C, Zhang PF, Li MY, Chen ZC: Differential proteomic analysis of nasopharyngeal carcinoma cell lines $5-8 \mathrm{~F}$ and 6-10B. Zhong Nan Da Xue Xue Bao Yi Xue Ban 2007, 32(6):978-984.

7. Xiang YL, Yi H, Li C, Zhang PF, Li MY, Chen ZC: Identification of metastasisrelated secretory proteins in human nasopharyngeal carcinoma cells. Int J Pathol Clin Med 2007, 27(3):369-375.

8. Frezza C, Gottlieb E: Mitochondria in cancer: not just innocent bystanders. Semin Cancer Boil 2009, 19(1):4-11.

9. Fogg VC, Lanning NJ, Mackeigan JP: Mitochondria in cancer: at the crossroads of life and death. Chin J Cancer 2011, 30(8):526-539. 
10. Lisanti MP, Martinez-Outschoorn UE, Chiavarina B, Pavlides S, WhitakerMenezes D, Tsirigos A: Understanding the "lethal" drivers of tumorstroma co-evolution: emerging role (s) for hypoxia, oxidative stress and autophagy/mitophagy in the tumor micro-environment. Cancer Biol Ther 2010, 10(6):537-542.

11. Bonuccelli G, Tsirigos A, Whitaker-Menezes D, Pavlides S, Pestell RG, Chiavarina B: Ketones and lactate "fuel" tumor growth and metastasis: evidence that epithelial cancer cells use oxidative mitochondria metabolism. Cell Cycle 2010, 9(17):3506-3514.

12. Pavlides S, Vera I, Gandara R, Sneddon S, Penstell RG, Mercier I: Warburg meets autophagy: cancer associated fibroblasts accelerate tumor growth and metastasis via oxidative stress, mitophagy and aerobic glycolysis. Antioxid Redox Signal 2012, 16(11):1264-1284.

13. Sotgia F, Martinez-Outschoorn UE, Lisanti MP: Mitochondria oxidative stress drives tumor progression and metastasis: should we use antioxidants as a key component of cancer treatment and prevention? BMC Med 2011, 9:62.

14. Pani G, Galeotti T, Chiarugi P: Metastasis: cancer cell's escape from oxidative stress. Cancer Metastasis Rev 2010, 29(2):351-378.

15. Weinberg F, Chandel NS: Reactive oxygen species-dependent signaling regulates cancer. Cell Mol Life Sci 2009, 66(23):3663-3673.

16. Miller TW, Isenberg JS, Roberts DD: Molecular regulation of tumor angiogenesis and perfusion via redox signaling. Chem Rev 2009, 109(7):3099-3124

17. Trachootham D, Lu W, Ogasawara MA, Nilsa RD, Huang P: Rodox regulation of cell survival. Antioxid Redox Signal 2008, 10(8):1343-1374.

18. Ralph SJ: Arsenic-based antineoplastic drugs and their mechanisms of action. Met Based Drugs 2008, :260146.

19. Thongwatchara P, Promwikorn W, Srisomsap C, Chokchaichamnankit D, Boonyaphiphat $P$, Thongsuksai $P$ : Differential protein expression in primary breast cancer and matched axillary node metastasis. Oncol Rep 2011, 26(1):185-191.

20. Ho JN, Lee SB, Lee SS, Yoon SH, Kang GY, Hwang SG: Phospholipase A2 activity of peroxiredoxin 6 promotes invasion and metastsis of lung cancer cells. Mol Cancer Ther 2010, 9(4):825-932.

21. Chang XZ, Li DQ, Hou YF, Wu J, Lu JS, Di GH: Identification of the functional role of peroxiredoxin 6 in the progression of breast cancer. Breast Cancer Res 2007, 9(6):R76.

22. Hempel N, Carrico PM, Melendez JA: Manganese superoxide dismutase (Sod2) and redox-control of signaling events that drive metastasis. Anticancer Agents Med Chem 2011, 11(2):191-201.

23. Nozoe T, Honda M, Inutsuka S, Yasuda M, Korenaga D: Significance of immunohistochemical expression of manganese superoxide dismutase as a marker of malignant potential in colorectal carcinoma. Oncol Rep 2003, 10(1):39-43.

24. Mohr A, Buneker C, Gough RP, Zwacka RM: MnSOD protects colorectal cancer cells from TRAIL-induced apoptosis by inhibition of Smac/DIABLO release. Oncogene 2008, 27(6):763-774.

25. Liu X, Wang A, Lo Muzio L, Kolokythas A, Sheng S, Rubini C: Deregulation of manganese superoxide dismutase (SOD2) expression and lymph node metastasis in tongue squamous cell carcinoma. BMC Cancer 2010, 10:365.

26. Salzman R, Kankova K, Pacal L, Tomandl J, Horakova Z, Kostrica R: Increased activity of superoxide dismutase in advanced staged of head and neck squamous cell carcinoma with locoregional metastases. Neoplasma 2007, 54(4):321-325.

27. Zhang J, Song M, Wang J, Sun M, Wang B, Li R: Enoyl coenzyme A hydratase 1 is an important factor in the lymphatic metastasis of tumors. Biomed Pharmacother 2011, 65(3):157-162.

28. Chou RH, Wen HC, Liang WG, Lin SC, Yuan HW, Wu CW: Suppression of the invasion and migration of cancer cells by SERPINB family genes and their derived peptides. Oncol Rep 2012, 27(1):238-245.

29. Goulet B, Kennette W, Ablack A, Postenka CO, Hague MN, Mymryk JS: Nuclear localization of maspin is essential for its inhibition of tumor growth and metastasis. Lab Invest 2011, 91(8):1181-1187.

30. Fukuda R, Zhang H, Kim JW, Shimoda L, Dang CV, Semenza GL: HIF-1 regulate cytochrome oxidase subunits to optimize efficiency of respiration in hypoxic cells. Cell 2007, 129(1):111-122.

31. Tang DJ, Dong SS, Ma NF, Xie D, Chen L, Fu L: Overexpression of eukaryotic initiation factor $5 \mathrm{~A} 2$ enhances cell motility and promotes tumor metastasis in hepatocellular carcinoma. Hepotology 2010, 51(4):1255-1263
32. Kim YO, Koh HJ, Kim SH, Jo SH, Huh JW, Jeong KS: Identification and functional characterization of a novel, tissue-specific NAD + -dependent isocitrate dehydrogenase beta subunit isoform. J Biol Chem 1999, 274(52):36866-36875.

33. Lee MS, Moon EJ, Lee SW, Kim MS, Kim KW, Kim YJ: Angiogenic activity of pyruvic acid in in vivo and in vitro angiogenesis models. Cancer Res 2001, 61(8):3290-3293.

34. Mayer RJ, Ciechanover A, Rechsteiner M: Protein degradation: the ubiquitinproteasome system and disease (volume 4). Weinheim: Wiley-VCH Verlag $\mathrm{GmbH} \&$ Co. KGaA; 2008:1-228.

35. Rahimi N: The ubiquitin-proteasome system meets angiogenesis. Mol Cancer Ther 2012, 11(3):538-548.

36. Finocchiaro G, Ito M, Ikeda $Y$, Tanaka K: Molecular cloning and nucleotide sequence of cDNAs encoding the alpha-subunit of human electron transfer flavoprotein. J Biol Chem 1988, 263(30):15773-15780.

37. Sato T, Sakamoto T, Takita K, Saito H, Okui K, Nakamura Y: The human prohibitin (PHB) gene family and its somatic mutations in human cancers. Genomics 1993, 17(3):762-764.

38. Coates PJ, Nenutil R, McGregor A, Picksley SM, Crouch DH, Hall PA: Mammalian prohibitin proteins respond to mitochondrial stress and decrease during cellular senescence. Exp Cell Res 2001, 265(2):262-273.

39. Marty L, Fort P: A delayed-early response nuclear gene encoding MRPL12, the mitochondrial homologue to the bacterial translational regulator L7/L12 protein. J Biol Chem 1996, 271(19):11468-11476.

40. Tang T, Zheng B, Chen SH, Murphy AN, Kudlicka K, Zhou H: hNOA1 interacts with complex I and DAP3 and regulates mitochondrial respiration and apoptosis. J Biol Chem 2009, 284(8):5414-5424.

41. Yu WH, Wolfgang W, Forte MA: Subcellular localization of human voltage-dependent anion channel isoforms. J Biol Chem 1995, 270(23):13998-14006.

42. Balchly-Dyson E, Zambronicz EB, Yu WH, Adams V, McCabe ER, Adelman JP: Cloning and functional expression in yeast of two human isoforms of the outer mitochondrial membrane channel, the voltage-dependent anion channel. J Biol Chem 1993, 268(3):1835-1841.

43. Vorum $\mathrm{H}$, Hager $\mathrm{H}$, Christensen BM, Nielsen S, Honore B: Human calumenin localizes to the secretory pathway and is secreted to the medium. Exp Cell Res 1999, 248(2):473-481.

44. Murayama K, Fujimura T, Morita M, Shindo N: One-step subcellular fractionation of rat liver tissue using a Nycodenz gradient prepared by freezing-thawing and two-dimensional sodium dodecyl sulfate electrophoresis profiles of the main fraction of organelles. Electrophoresis 2001, 22(14):2872-2880.

45. Yang YX, Xiao ZQ, Chen ZC, Zhang GY, Yi H, Zhang PF: Proteome analysis of multidrug resistance in vincristine-resistant human gastric cancer cell line SGC7901/VCR. Proteomics 2006, 6(6):2009-2021.

doi:10.1186/1755-8794-5-62

Cite this article as: Liu et al:: Mitochondrial proteomics of nasopharyngeal carcinoma metastasis. BMC Medical Genomics 2012 5:62.

\section{Submit your next manuscript to BioMed Central and take full advantage of:}

- Convenient online submission

- Thorough peer review

- No space constraints or color figure charges

- Immediate publication on acceptance

- Inclusion in PubMed, CAS, Scopus and Google Scholar

- Research which is freely available for redistribution 